\title{
Molecular aetiology and pathogenesis of basal cell carcinoma.
}

Citation for published version (APA):

Tilli, C. M. L. J., van Steensel, M. A. M., Krekels, G. A. M., Neumann, H. A. M., \& Ramaekers, F. C. S. (2005). Molecular aetiology and pathogenesis of basal cell carcinoma. British Journal of Dermatology, 152, 1108-1124. https://doi.org/10.1111/j.1365-2133.2005.06587.x

Document status and date:

Published: 01/01/2005

DOI:

10.1111/j.1365-2133.2005.06587.x

Document Version:

Publisher's PDF, also known as Version of record

\section{Please check the document version of this publication:}

- A submitted manuscript is the version of the article upon submission and before peer-review. There can be important differences between the submitted version and the official published version of record. People interested in the research are advised to contact the author for the final version of the publication, or visit the DOI to the publisher's website.

- The final author version and the galley proof are versions of the publication after peer review.

- The final published version features the final layout of the paper including the volume, issue and page numbers.

Link to publication

\footnotetext{
General rights rights.

- You may freely distribute the URL identifying the publication in the public portal. please follow below link for the End User Agreement:

www.umlib.nl/taverne-license

Take down policy

If you believe that this document breaches copyright please contact us at:

repository@maastrichtuniversity.nl

providing details and we will investigate your claim.
}

Copyright and moral rights for the publications made accessible in the public portal are retained by the authors and/or other copyright owners and it is a condition of accessing publications that users recognise and abide by the legal requirements associated with these

- Users may download and print one copy of any publication from the public portal for the purpose of private study or research.

- You may not further distribute the material or use it for any profit-making activity or commercial gain

If the publication is distributed under the terms of Article $25 \mathrm{fa}$ of the Dutch Copyright Act, indicated by the "Taverne" license above, 


\title{
Molecular aetiology and pathogenesis of basal cell carcinoma
}

\author{
C.M.L.J. Tilli, ${ }^{\star} \dagger+$ M.A.M. Van Steensel, ${ }^{\star} \dagger$ G.A.M. Krekels, ${ }^{\star} \dagger$ H.A.M. Neumann ${ }^{\star} \S$ and F.C.S. Ramaekers ${ }^{\star} \ddagger$ \\ *Research Institute of Growth \& Development (GROW), Departments of †Dermatology and \$Molecular Cell Biology, University of Maastricht, The Netherlands \\ $\S$ Department of Dermatology \& Venereology, Erasmus University Rotterdam, The Netherlands
}

\section{Summary}

\section{Correspondence \\ FCS Ramaekers. \\ E-mail: f.ramaekers@molcelb.unimaas.nl \\ Accepted for publication \\ 12 August 2004}

\section{Key words:}

basal cell carcinoma, cancer, cell signalling,

epidermal stem cells, heredity, therapy
Recent insights into the cell biology of the epidermis and its appendages are transforming our understanding of the pathogenesis of basal cell carcinoma (BCC). The significant progress that has been made warrants a comprehensive review of the molecular and cellular pathology of BCC. The items addressed include environmental and genetic risk factors, the biology of the putative precursor cell(s), and the contribution of aberrations in processes such as apoptosis, cell proliferation, differentiation and signalling to carcinogenesis. Furthermore, established and novel treatment modalities are discussed with particular attention to future biological approaches.

Conflicts of interest:

None declared.

Basal cell carcinoma (BCC), also called basalioma, basal cell epithelioma, rodent ulcer and Jacobs' ulcer, was first described in $1824^{1}$ and is the most common cancer among Caucasians. ${ }^{2}$ BCC accounts for approximately $75 \%$ of all skin cancers. Mortality rates are low, ${ }^{3}$ but BCC may occasionally grow aggressively causing extensive tissue destruction. ${ }^{4}$ Its frequency of metastasis is very low $(<0 \cdot 1 \%){ }^{5}$ Metastasis to lymph nodes, lung, bone and liver has been described. ${ }^{6,7}$

$\mathrm{BCCs}$ are commonly subdivided according to their differences in histological appearance. ${ }^{8,9}$ The major histological patterns are nodular, micronodular, superficial and morpheaform BCC. The nodular type is characterized by a rounded mass of neoplastic cells with well-defined peripheral contours and peripheral palisading. The superficial type is defined by one or more tumour foci that extend from the epidermis into the papillary dermis. Peripheral palisading occurs and the peripheral contours are smooth. The micronodular subtype grows as small nodules, hence the name. Peripheral palisading is usually present. The morpheaform subtype consists of tumour islands of varying size with an irregular outline and spiky configuration. Peripheral palisading is poorly developed. Mixed types of these histological patterns may occur, with the nodularmicronodular combination being the most common. ${ }^{10}$ Furthermore, central nodular and peripheral morphea-like growth can occur. Finally, a so-called adenoid pattern is seen in $1-7 \%$ of the tumours and is mainly associated with the nodular growth type. ${ }^{11}$ Nodular $(\sim 60 \%)$ and superficial ( 25\%) BCCs are often considered as non-aggressive subtypes, whereas morpheaform $(\sim 2 \%)$ and micronodular $(\sim 15 \%)$ BCCs are often referred to as aggressive subtypes, associated with a higher risk of local recurrence. ${ }^{12}$

\section{Risk factors}

The risk for development of BCC is associated with environmental factors as well as several patient-dependent factors.

\section{Environmental risk factors}

\section{Sun exposure}

BCCs generally occur on sun-exposed areas of the body ${ }^{13}$ and high-risk patients are often fair-skinned with a history of burning, not tanning, when exposed to sunlight. ${ }^{14}$ Male sex, older age and number of previous second-degree sunburns are also factors indicating a higher risk for development of BCC. ${ }^{15}$ Corona et al. ${ }^{16}$ showed in 2001 that there is a significant association between BCC development and recreational sun exposure during childhood and adolescence, as well as a strong relationship with family history of skin cancer. Patients with a BCC located on the trunk are at increased risk of developing multiple BCCs, and these tumours develop at a faster rate than BCCs located elsewhere on the body. ${ }^{17}$ Grossman and Leffell ${ }^{18}$ showed that there is a correlation between ultraviolet (UV)-B exposure and the development of skin cancer. However, the significant number of BCCs arising on non-sunexposed areas of the body suggests that other risk factors may play a role in the development of $\mathrm{BCC} .{ }^{19}$

\section{Chemical carcinogens and radiation}

Diepgen and Mahler ${ }^{20}$ found that chemical carcinogens such as arsenic, coal tar products and psoralens as well as ionizing 
radiation increase the risk of non-melanoma skin cancer, mainly squamous cell carcinoma (SCC). With respect to the relationship between smoking and skin cancer development, de Hertog et al. ${ }^{21}$ showed an association with SCC but not BCC, while Boyd et al. ${ }^{22}$ recently proved that an association exists between smoking and BCC in young women. Furthermore, exposure to fibreglass dust and dry-cleaning agents has also been reported to enhance the risk for BCC development. ${ }^{19}$ However, this is one report and the findings in it have yet to be confirmed. We find it difficult to think of a pathogenic mechanism to explain the carcinogenic potential of fibreglass on skin.

Exposure to psoralens combined with UVA-treatment (PUVA) in psoriasis patients has been reported to result in an increased risk for BCC and SCC. ${ }^{23-25}$ However, later studies failed to substantiate the increased risk of BCC and it is currently doubted whether BCC can really result from PUVA therapy. ${ }^{26,27}$ Melanoma risk is also increased by PUVA. ${ }^{27}$ Prior non-diagnostic X-ray treatment for skin conditions also enhanced the risk for BCC. ${ }^{19}$ In general, it seems that DNAdamaging agents predispose more to SCC than they do to BCC. This observation is consistent with the spectrum of malignancies observed in congenital disorders of DNA repair (discussed below).

\section{Viral carcinogenesis}

Several authors demonstrated an association between infection with the oncogenic types of human papillomavirus (HPV) and development of $\mathrm{BCC},{ }^{28-30}$ while Harwood and Proby ${ }^{31}$ showed that HPV could abrogate UV-induced apoptosis. Furthermore, HPV DNA was detected in BCC patients by Barr et al. $^{28}$ and Weinstock et al. ${ }^{30}$ suggesting that HPV infection may play a role in developing BCC. To date, a causal connection has not been established and it seems doubtful that one will be found.

\section{Hereditary predisposition}

\section{Detoxifying proteins}

Proteins that mediate detoxification processes, including individual responses to UV irradiation by protecting from oxidative stress, are likely to be involved in susceptibility for BCC. ${ }^{32}$ For example, glutathione S-transferase (GST) enzymes are part of the cells' defence mechanism against harmful chemicals produced endogenously and in the environment. ${ }^{33} \mathrm{UV}$ irradiation causes oxidative stress in the skin, which leads to lipid peroxidation and DNA hydroperoxide formation. ${ }^{34}$ GST is responsible for the disposal of these potential mutagens. ${ }^{35}$ Cytosolic GST activity in mammalian tissues is due to the presence of multiple GST isozymes, which can be assigned to five classes, e.g. $\alpha, \theta, \mu, \pi$ and $\sigma .^{36}$ In human skin, GST activity is found predominantly in sebaceous glands and in the outer root sheath (ORS) of hair follicles, the $\pi$-class of GST being the predominant isozyme. ${ }^{37}$ GST- $\pi$ has been suggested to be an oncofetal protein that is re-expressed during carcinogenesis. ${ }^{38}$ A significant increase in skin tumorigenesis is observed in mice lacking $\pi$-class GST. ${ }^{39}$ This finding seems to contradict the oncogene hypothesis, but in humans, GST- $\pi$ is expressed in malignant melanomas, ${ }^{40}$ whereas BCCs show only a weak expression of the protein. ${ }^{41}$ Obviously, this apparent contradiction needs to be addressed if we are to understand the role of GST- $\pi$ in human tumorigenesis, if any. Conditional (skinspecific) GST- $\pi$ knockout mice could be used as a model system. Several polymorphisms in GST family members exist $^{36,42}$ and have been associated with impaired detoxification, thus influencing the risk for several cancers, including non-melanoma skin cancer. ${ }^{43,44}$ A GSTT1 null genotype is associated with high UV sensitivity, ${ }^{45}$ and a GSTM1 null genotype also predisposes for BCC, probably due to its role in defence against UV-induced oxidative stress. ${ }^{32,46}$ Polymorphism of GSTM3 was also shown to increase risk for BCC. ${ }^{47}$ Another genetic factor involved in detoxification of photosensitizing agents, and thus involved in BCC carcinogenesis, is polymorphism of CYP2D6 (the gene encoding cytochrome P450), which is correlated with an increased number of BCCs. ${ }^{46}$ Furthermore, some allelic variants of CYP2D6 are associated with a multiple presentation phenotype of $\mathrm{BCC}^{48,49}$ and these patients are also at higher a priori risk for developing BCC. ${ }^{50}$

\section{DNA repair}

In 1973, Milstone and Helwig ${ }^{51}$ noted that patients with xeroderma pigmentosum (XP), a group of rare autosomal recessive disorders characterized by severe photosensitivity due to various defects in DNA repair, are prone to developing cutaneous cancers, mostly SCC but also BCC and malignant melanoma. $^{52-54}$ There are several variants of the disease, all caused by a different genetic defect in nucleotide excision repair, global genome repair, transcription-coupled repair or combinations thereof. Some of the genes involved are essential components of the TFIIH transcription complex; their absence is associated not only with UV sensitivity but also with sometimes severe neurological defects and growth retardation (as in de Sanctis-Cacchione syndrome). ${ }^{55}$ Interestingly, at least two types of XP are caused by defects in DNA helicases that are involved in nucleotide excision repair and in transcription. Werner and Bloom syndromes are hereditary skin cancer disorders that are associated with helicase defects but, curiously, not with the development of BCCs. ${ }^{56,57}$ Rothmund-Thomsen syndrome, which in some cases is caused by defects in a DNA helicase, ${ }^{58}$ does seem to predispose to BCC. ${ }^{59}$ The reason for this difference is poorly understood. The expression patterns of helicases may play a role but it is not clear why helicases should be tissue-specific. Chromosomal breakage disorders such as ataxia teleangiectasia and Nijmegen breakage syndrome do not predispose to BCC. Neither does Li-Fraumeni syndrome, which can be caused by germline mutations in the p53 gene, ${ }^{60}$ nor dyskeratosis congenita, a disorder associated with failure to maintain telomeres. ${ }^{61,62}$ Why these forms of genomic instability do not seem to be causally related to BCC 
is uncertain. It may reflect a very basic biological difference between BCC and other malignancies. Whereas most tumours sooner or later show chromosomal instabilities, ${ }^{63}$ BCC does not seem to do so.

Embryonic signalling pathways - Hedgehog, Wingless, Ectodysplasin and NF-kB

Patients with the nevoid BCC syndrome (NBCCS) or Gorlin syndrome, ${ }^{64}$ show a rapid development of numerous BCCs at a young age. Whereas $\mathrm{XP}$ is an autosomal recessive disorder, NBCCS is an autosomal dominant disorder. ${ }^{65} \mathrm{~A}$ human homologue to the Drosophila segment polarity gene patched, PTCH1 (there is also a PTCH2 of as yet unknown importance) is mutated in NBCCS patients, suggesting a contribution to the tumorigenesis. ${ }^{66,67}$ As NBCCS patients normally inherit one mutated copy of the PTCH gene, tumours are likely to arise after inactivation of the remaining allele. ${ }^{68}$ Haploinsufficiency of the PTCH1 gene is probably responsible for the dysmorphisms. XP patients and sporadic BCCs may also show mutations in the PTCH gene. ${ }^{69-71}$ The PTCH1 gene product is part of a receptor for a protein called Sonic Hedgehog, which is involved in embryonic development. ${ }^{72}$ Sonic hedgehog (SHH) is expressed in the Hensen node, the floorplate of the neural tube, the early gut endoderm, the posterior limb buds and throughout the notochord, and encodes a signal responsible for patterning the early embryo. ${ }^{73-75}$ When SHH binds to $\mathrm{PTCH}$, it releases smoothened (SMOH), a transmembrane signalling protein, from inhibition by PTCH (Fig. 1). ${ }^{76}$ It is now believed that PTCH modulates SMOH in an indirect manner, ${ }^{77}$ although it is not known how. There is some evidence that PCTH may influence the localization or intramembrane conformation of $\mathrm{SMOH} .{ }^{78} \mathrm{SMOH}$ in turn signals to GSK3 $\beta$, which phosphorylates GLI3 (a human ortholog of the Drosophila gene cubitus interruptus). It is assumed that the human orthologues of Costal2, Fused and Suppressor of Fused $(\mathrm{Su}(\mathrm{Fu}))$ then form a tetramer as they do in Drosophila but so far, only $\mathrm{Su}(\mathrm{Fu})$ has been demonstrated in humans. ${ }^{79}$ The complex then translocates, possibly via the microtubulebinding activity of Costal2, which has kinesin activity, to the nucleus where it can regulate activity of target genes such as WNT genes, BMP and PTCH1 itself (Fig. 1 and reviewed $\mathrm{in}^{80}$ ). WNT signals are transduced via the APC/Axin/DSH complex which inhibits GSK3 $\beta$ activity; as a result, $\beta$-catenin is not degraded and complexes with TCF/Lef1 into a transcription complex which is active in early hair follicle growth and in the initiation of anagen. ${ }^{81} \beta$-catenin, in turn, can influence the NFkB pathway (see below). Activating mutations of $\beta$-catenin give rise to pilomatricoma, another hair follicle tumour, clearly showing the importance of $\beta$-catenin-mediated signalling for hair follicle growth. ${ }^{82,83}$ Such mutations have not yet been found in BCC, and it would be of interest to look for such alterations in sporadic BCCs. Thus, a staggeringly complex regulatory network emerges. It is of interest to note that it is essential for hair

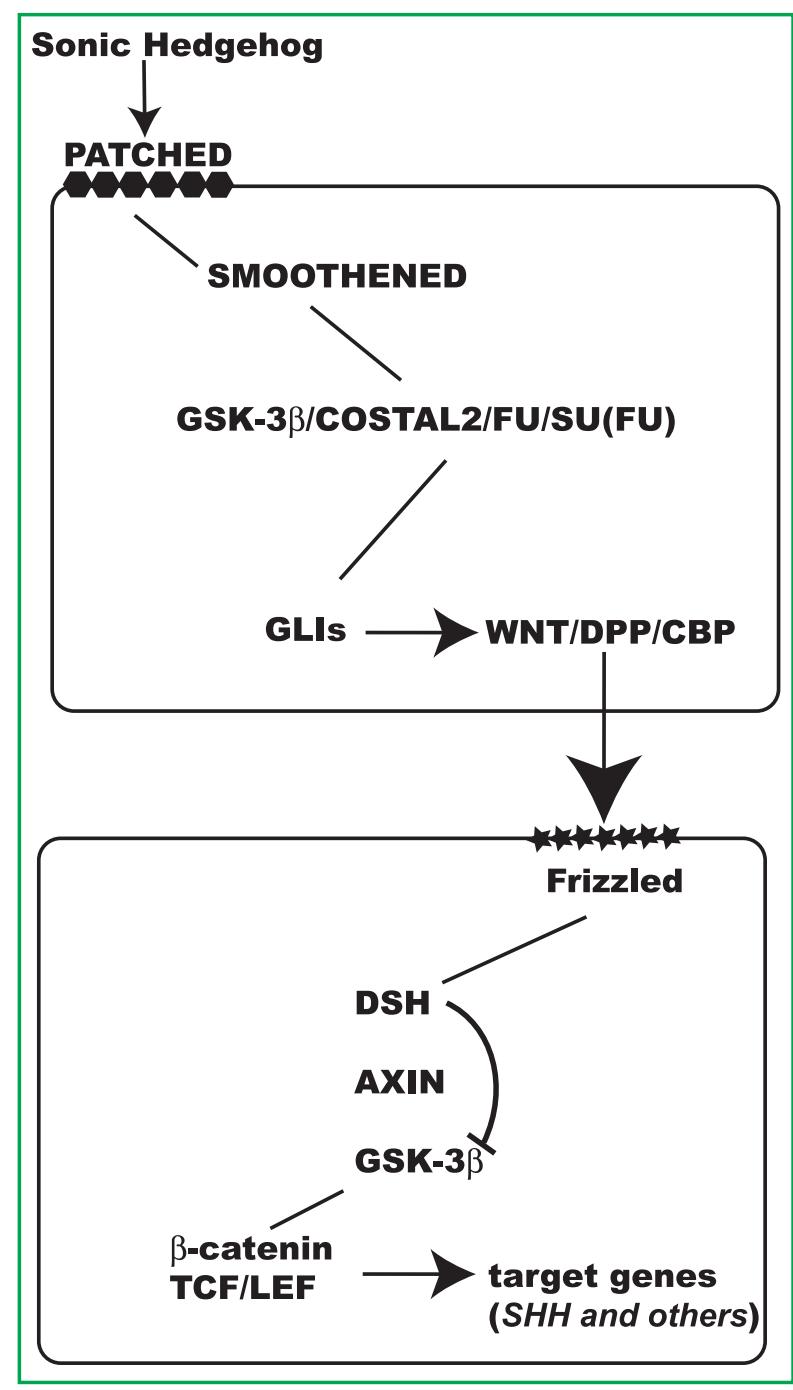

Fig 1. A simplified representation of the Sonic Hedgehog signalling network and its cross-talk with the Wnt signalling pathway. See the text for an explanation. GSK3 $\beta$, glycogen synthetase kinase $3 \beta$; FU, Fused; SU(FU), suppressor of fused; GLI, cubitus interruptus homologues; BMP, bone morphogenetic proteins; WNT, secreted Wingless signalling protein; CBP, CREB binding protein; TCF/LEF, transcription control factor/lymphoid enhancer factor; DSH, dishevelled family protein; APC, adenomatous polyposis coli protein.

follicle morphogenesis, suggesting that the development of $\mathrm{BCC}$ in the context of PTCH1 mutations may represent uncontrolled hair follicle morphogenesis.

The high frequency of mutations in SMOH and PTCH1 in $\mathrm{BCCs}$, resulting in continuous activation of target genes, indicates that a disturbed HEDGEHOG pathway, resulting in excessive signalling, may be an important carcinogenic route. ${ }^{84} \mathrm{UV}$ irradiation enhances BCC development in PTCH1 mutant mice. $^{85}$ Of the sporadic BCCs $20 \%$ show SMOOTHENED mutations ${ }^{86}$ and $30-40 \%$ patched mutations. ${ }^{70}$ In XP patients, the majority $(\sim 80 \%)$ of PTCH1 mutations are UV-induced, ${ }^{87}$ as expected more frequently than in sporadic BCCs, ${ }^{70}$ where UV-signature mutations are seen in less than $50 \%{ }^{88}$ PTCH2, 
which is $57 \%$ identical to PTCH1, probably also serves as a receptor for hedgehog and related factors. ${ }^{89}$ Mutations occur in sporadic BCC, ${ }^{90}$ and it has been shown that when PTCH1 is mutated, PTCH2 mRNA is up-regulated. ${ }^{89}$

\section{NFkB}

A good example of the importance of embryonic growth regulatory pathways in BCC carcinogenesis is the discovery that defects in one of the components of the NFkB signalling pathway can also cause BCC (own data, unpublished). The CYLD gene, which is mutated in familial cylindromatosis or BrookeSpiegler syndrome, is a de-ubiquitinating enzyme that negatively regulates NFkB. ${ }^{91-93}$ Its target is TNFR-associated factor 2 (TRAF2) and, to a lesser extent, TRAF6. Both TRAF2 and TRAF6 are implicated in the transduction of EDA/EDAR/ EDARADD signals ${ }^{94-97}$ and thus in the development of skin appendages, as mutations in EDA, EDAR, EDARADD and TRAF6 can all cause ectodermal dysplasias in humans and mice. ${ }^{96,98-100}$ Recent data indicate that EDA can repress $\beta$-catenin-dependent transcription, ${ }^{101}$ suggesting a regulatory connection between the EDA and PCTH pathways and hinting, again, at the central importance of the PTCH route for basal cell carcinogenesis. $\beta$-Catenin can control EDAR expression, showing that the EDA-NFkB pathway is subject to negative autofeedback.

Normally, activation of NFkB is caused by phosphorylation of the NFkB inhibitor IkB through the IkB kinase complex. ${ }^{102}$ The gene mutated in incontinentia pigmenti, NEMO (NFkB essential modulator), is part of the IkB kinase complex. Phosphorylation of $\mathrm{IkB}$ leads to its ubiquitination and subsequent disposal through the proteasome. CYLD was found to interact with NEMO. ${ }^{91-93}$ This possibly transient interaction is required for its function, the de-ubiquitination of TRAF2 and TRAF6. The latter proteins are auto-ubiquitinating and need the ubiquitin tag for their normal function. Hence, CYLD down-regulates NFkB activation. Interestingly, CYLD mutations were recently found in familial trichoepithelioma. The latter tumour is also observed in familial cylindromatosis and resembles BCC to such a degree that a distinction is often difficult to make. ${ }^{103}$ Indeed, we have recently observed the occurrence of a $\mathrm{BCC}$ in a patient suffering from familial cylindromatosis. These observations suggest that the NFkB pathway, which is involved in inflammation and in the embryogenesis of epithelial appendages, can also play a role in BCC. It should be of interest to examine sporadic BCCs for mutations in one of the components of the NFkB pathway. Likewise, patients suffering from multiple BCCs may harbour CYLD mutations.

\section{Unknowns}

Finally, Rombo and Bazex syndromes are known to predispose to BCC. Both are characterized by the presence of numerous small cysts on the face and chest, as well as by hypotrichosis. The cysts contain vellus hairs. ${ }^{104,105}$ Rombo syndrome is distinguished by striking degeneration of elastic fibrils in sunlight-exposed areas causing dramatic skin alterations called atrophoderma vermiculatum. ${ }^{104,105}$ In Bazex syndrome, so-called ice-pick scars are seen on the backs of the hands. This disorder is X-linked and has been mapped to Xq2427. ${ }^{106}$ Rombo syndrome is probably autosomal dominant, but otherwise very similar to Bazex. Identification of the causative genes should contribute significantly to our knowledge of hair follicle and BCC biology.

\section{Acquired genetic changes in basal cell carcinoma}

\section{p53}

The most common genetic aberrations in human skin cancers are found at the level of the p53 gene. ${ }^{107}$ The p53 gene encodes a phosphoprotein that is involved in cell-cycle control and the maintenance of chromosomal stability. ${ }^{108,109}$ In response to cellular stress, for example DNA damage, p53 is activated through phosphorylation. ${ }^{110,111}$ MDM2 can associate with p53 and regulates its level and activity depending on the phosphorylation status of p53. When dephosphorylated, p53 will bind to MDM2 and is then degraded through the ubiquitin-proteosome pathway. ${ }^{12,113}$ In response to DNA damage, p53 is phosporylated by DNA damage-sensing proteins such as ATM and becomes detached from MDM2, resulting in stabilization and activation of target genes regulated by $\mathrm{p} 53$ (Fig. 2). ${ }^{114}$ The response to DNA damage is either growth arrest, senescence or apoptosis. ${ }^{115}$ The relative cellular content of p53 determines the response following DNA damage; when the content is low to moderate, cells will go into cell-cycle arrest to allow DNA repair, but when p53 levels are high, cells will progress to apoptosis. ${ }^{116}$ p53 is capable of stimulating proapoptotic Bax expression ${ }^{17,118}$ (see also below). In normal skin, wild type p53 is not detectable but appears within $2 \mathrm{~h}$ after UV irradiation, with peak levels at $24 \mathrm{~h}$ after irradiation and again undetectable levels at $36 \mathrm{~h}$ after irradiation. ${ }^{119}$ Mutant p53 can accumulate in cells and p53 mutations have been detected in about half of all BCCs. ${ }^{120,121}$ Furthermore, it was found that histologically proven aggressive BCCs are significantly associated with increased p53 expression, probably representing the mutated form although that assertion could not be established with certainty. However, it is striking that patients suffering from Li-Fraumeni syndrome do not show increased incidence of BCC. Consequently, it seems reasonable to assume that p53 mutations are secondary events in BCCs, occurring after tumour initiation. Considering the apparently limited contribution of DNA damage and chromosome instability to the $\mathrm{BCC}$ phenotype, the relevance of p53 mutations for BCC growth remains to be demonstrated. After all, in the absence of genetic damage, p53 activation will not occur. Moreover, one of the hallmarks of p53 dysfunction, aberrant mitosis, perhaps as a consequence of centrosome amplification, ${ }^{122}$ has never been observed in BCC. ${ }^{123}$

In BCC patients, in a study comparing sunscreen users and non-users, it was shown that sunscreen users showed a significantly lower level of p53 mutations in their BCCs than 


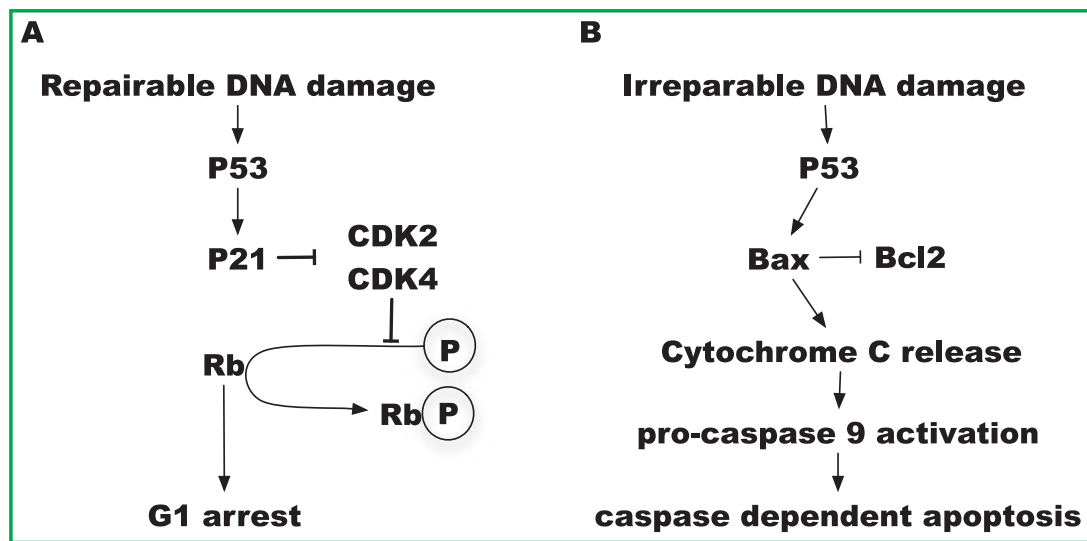

Fig 2. p53 signalling. DNA damage induces stabilization of p53. In the case of repairable damage (A), p53 triggers p21. This in turn inhibits cyclin-dependent kinases. As a consequence, Rb remains unphosphorylated and stalls the cell in the G1 phase of the cell cycle. In the case of irreparable DNA damage (B), p53 also induces Bax which then competes with Bcl2 in the mitochondrial membrane. As a result, cytochrome C is released from the mitochondria, triggering the caspase cascade that causes apoptosis.

non-users, ${ }^{124}$ again suggesting that 553 mutations in BCCs are secondary events that may not contribute significantly to tumorigenesis. Mutational hotspots have been identified, with two-thirds of the mutations occurring at nine different sites. ${ }^{125}$ Inactivation of $\mathrm{p} 53$ occurs predominantly by point mutation of one allele followed by loss of the remaining wild-type allele. ${ }^{126}$ The p53 gene shows UV signature mutations, i.e. predominantly $\mathrm{C}(\mathrm{C}) \rightarrow \mathrm{T}(\mathrm{T})$ conversions. ${ }^{125,127}$ In $33 \%$ of $\mathrm{BCCs}$ found in Korean patients $\mathrm{p} 53$ mutations were detected $^{69}$ and up to $50 \%$ of the BCCs in Caucasian patients showed this mutation, ${ }^{120,121}$ thus suggesting that different ethnic factors play a role in BCC carcinogenesis although differences in sun exposure (with the Westerners engaging more in recreational sunning) may just as well account for the differences observed.

\section{p63}

The p63 gene, a p53 homologue, encodes multiple products and is restricted to cells with high proliferation potential and absent from cells undergoing terminal differentiation. ${ }^{128}$ p63 has a nucleoplasmic distribution pattern in the basal compartment of stratified epithelia such as skin, tonsil, bladder and certain subpopulations of basal cells in prostate, breast, uterine cervix and bronchi. ${ }^{129-131}$ p63-deficient mice have striking developmental defects such as absence or truncation of limbs, absence of hair follicles, teeth and mammary glands, and the skin lacks stratification and differentiation. ${ }^{132}$ This indicates that p63 is essential for several aspects of differentiation during embryogenesis. Several isoforms of p63 can bind to p53 consensus sequences and activate p53 target genes. Isoform TAp63 $\gamma$ is capable of inducing cell-cycle arrest and apoptosis. ${ }^{133}$ The $\Delta \mathrm{N}$ isoforms, lacking the $\mathrm{N}$-terminus, are unable to induce transcription, and have an antiapoptotic effect by rendering p53 and TA isoforms inactive. p63 is only rarely mutated in BCC. ${ }^{134}$ It was shown that p63 functions not only as a stem-cell marker of keratinocytes ${ }^{135}$ but may also maintain the stem-cell phenotype. ${ }^{136}$ In keeping with its basal localization in normal epidermis, BCC cells express p63. ${ }^{131,137}$ It was shown that aberrant expression of p63 altered the UVB-induced apoptotic pathway suggesting that down-regulation of this protein in response to UV irradiation is important in epidermal apoptosis. ${ }^{138}$

\section{Immunological factors}

Immunosuppression

Organ transplant recipients are at greater risk for developing malignancies because of the prolonged, often life-long, immunosuppressive therapy. ${ }^{139-141}$ SCC of the skin is the most common malignancy occurring in the setting of solid-organ transplantation and immunosuppression, and its incidence increases substantially with extended survival after transplantation. ${ }^{142}$ SCC occurs more frequently in transplant patients, ${ }^{143}$ whereas in the general population BCC is three to six times more frequent than SCC. ${ }^{144}$ It was shown in Australian heart transplant recipients that the number of skin cancers is significantly correlated with both age at transplantation and duration of follow-up. ${ }^{145}$ In Europe, $40 \%$ of renal transplant recipients develop skin cancer within 20 years after grafting. ${ }^{146}$ Heart transplant recipients are at higher risk than kidney transplant recipients most probably due to the fact that they receive higher doses of immunosuppression agents, ${ }^{147}$ but it cannot be overlooked that the different types of immunosuppressive agents have different effects in this respect. Increased incidence of BCC has not been described in organ recipients. From the available data, it seems clear that immunosuppression as practised after organ transplantation does not increase the risk of developing BCC. As stated above, the incidence of BCC seems not to be affected by PUVA treatment. A diminished response to skin application of dinitrochlorobenzene was found in people with SCC but not in patients with BCC, again supporting the notion that the incidence of $\mathrm{BCC}$ is not affected by immune status. ${ }^{148}$ 


\section{Human immunodeficiency virus}

Seemingly in contradiction to the lack of an increase in the incidence of BCC in organ recipients, people suffering from acquired immune deficiency syndrome (AIDS) have shown an elevated risk for the development of $\mathrm{BCC} .{ }^{149,150}$ Human immunodeficiency virus (HIV) patients with BCC more frequently show blue eyes, blond hair, family history and extensive prior sun exposure. ${ }^{151}$ The pigmentation phenotype is probably an independent risk factor that is added to the increased risk of BCC conferred by the immunosuppression. There have been some reports of BCCs metastasizing in people suffering from AIDS, ${ }^{152,153}$ suggesting that immune surveillance is one of the factors determining the normally nonmetastatic nature of the BCC. Why immunosuppression by HIV increases the risk of BCC, whereas pharmaceutical immunosuppression does not is not clear. The depletion of CD4 lymphocytes by HIV may lead to a more pervasive defect in adaptive antitumour immunity than does mere functional suppression by commonly used immunosuppressive compounds.

\section{Human leucocyte antigen (HLA) haplotypes}

The major histocompatibility complex (MHC) genes code for membrane proteins that play important roles in controlling immune responses. ${ }^{154}$ There are two classes of genes, class I (HLA-A, -B, -C) and class II (HLA-DR, -DQ, -DP), which play a role in host defence against the development and spread of tumours. ${ }^{155}$ For example, loss of class I antigens is related to tumour progression in melanomas. ${ }^{156}$ Furthermore, abnormalities in cell-mediated immunity have been reported in patients with multiple BCCs. ${ }^{157}$ Whereas normal skin shows high levels of class I molecules, BCC shows either complete absence or heterogeneous expression. ${ }^{158}$ All class I-negative tumours were histologically proven to be aggressive, whereas all non-aggressive BCCs were class I-positive. The low levels or absence of expression of class I antigens may result in escape from recognition by cytotoxic $\mathrm{T}$ cells, which then facilitates tumour growth. ${ }^{159}$ Evidence for the involvement of HLA genes in the development of skin cancer was provided by Bouwes Bavinck et al. ${ }^{160}$ These authors showed that the presence of HLADR7 and a decrease of HLA-DR4 are significantly associated with BCC. This corroborates the previous finding of Rompel et al. ${ }^{161}$ that HLA-DR4 is decreased in BCC, especially in patients with multiple BCCs located on the trunk. ${ }^{162}$ The authors suggested a protective role for HLA-DR4 against the development of BCC. HLA-DR1 is weakly associated with the development of multiple BCCs at an early age. ${ }^{163}$ Furthermore, Bouwes Bavinck et al. presented two studies showing a correlation between HLA-A11 expression and skin cancer in immunosuppressed renal transplant recipients. ${ }^{164,165}$ One of these studies showed that HLA-A11 was associated with resistance to skin cancer in renal transplant recipients, ${ }^{164}$ while another study, in Australia, showed that renal transplant recipients with HLA-A11 had an increased risk for developing skin cancer. ${ }^{165}$ This apparent discrepancy may be the result of different genetic backgrounds and differential environmental factors.

\section{Human papillomavirus}

Although HPV has been associated strongly with malignant progression of warts to SCC and with epidermodysplasia verruciformis, ${ }^{166}$ different oncogenic subtypes of the virus were found in $60 \%$ of BCCs from immunosuppressed patients in contrast to $36 \%$ of BCCs from non-immunosuppressed patients, suggesting that these viruses may be involved in the development of BCC. ${ }^{167}$ In renal transplant recipients with skin cancer HPV 5/8 DNA could be detected, ${ }^{28}$ and Weinstock et al. $^{30}$ suggested immunosuppression to be a factor in BCC carcinogenesis by affecting HPV infection.

\section{Tumour stem cells}

Several cell types have been suggested to be the precursor cells or stem cells for BCC: interfollicular basal keratinocytes, basal keratinocytes from hair follicles or sebaceous gland cells. ${ }^{168-173}$ In general, stem cells have a relatively undifferentiated and slow-cycling phenotype, but can be stimulated to proliferate and give rise to transient amplifying cells which have a limited proliferative potential. ${ }^{174}$ Stem cells may be the target of carcinogens and as such play an important role in tumorigenesis. One observation suggesting that uncommitted stem cells are the most likely cells of origin for human skin cancer is the fact that sunlight exposure in childhood may contribute to tumours many decades later. ${ }^{175}$ As first suggested by Taylor et al. ${ }^{176}$ the ultimate source of stem cells in the skin is the bulge region of the ORS. ${ }^{177-179}$ As a result, hair follicles are likely to play an important role in skin homeostasis, wound healing and tumourigenesis. ${ }^{174}$ Chemically induced BCCs in rats arise from hair follicles, ${ }^{180}$ but it is not known whether this is also the case in humans.

Histologically, BCCs may resemble hair follicles, ${ }^{11}$ and may show characteristics from both bulge region stem cells and transient amplifying cells. ${ }^{181}$ In particular, BCC can histologically resemble trichoepithelioma, a benign hair follicle tumour. ${ }^{182}$ The suprabulbar region of the ORS of the hair follicle has an immunohistochemical profile that is almost indistinguishable from that of a BCC. ${ }^{169,183,184}$ The hair follicle hypothesis is further supported by the fact that when a carcinogen is added in the anagen phase, in which the hair follicle bulge region cells undergo transient amplification, BCCs are generated more frequently. ${ }^{185}$ Furthermore, BCCs seldomly occur on non-hairy skin. ${ }^{181}$ Support for the hair follicle hypothesis can be found in the expression of the basal cell adhesion molecule (B-CAM) in normal and diseased skin. ${ }^{186}$ The fact that this cell-surface protein is preferentially expressed in suprabasal cell layers and the ORS of the hair follicle, and also shows high levels of expression in BCCs, suggests that BCCs originate from hair follicles rather than from basal keratinocytes, which are negative for B-CAM in 
normal skin. However, the lack of cytokeratin 15 expression in the tumour cells suggests that BCCs do not differentiate towards a hair bulge cell fate. ${ }^{187}$

Howell and Mehregan ${ }^{188}$ reported that the tiny pits in the epidermis of palms and soles characteristic of Gorlin syndrome $^{64}$ (or NBCCS, see above) occasionally show basaloid budding into the dermis, and have therefore suggested that they resemble tiny BCCs. This observation was taken to support the idea that BCCs can originate from interfollicular epidermis. There is no further proof to support this notion. Finally, our current understanding of the molecular genetics of BCC as outlined above also supports the notion that the hair follicle stem cell is the progenitor cell of the BCC. In all, it seems as if the BCC cell is a hair follicle stem cell in which the normal differentiation and anagen-initiation programme, of which the SHH network forms the backbone, has gone awry.

\section{Carcinogenesis}

Tumour formation results from a disruption of the normal balance between cell proliferation and cell death. ${ }^{189}$ Three large categories of genes affect cellular proliferation and survival, i.e. growth-promoting oncogenes, tumour suppressor genes and mutator or caretaker genes. ${ }^{190}$ The normal counterparts of oncogenes, i.e. the proto-oncogenes, are crucial in regulating normal cell cycling and division, differentiation and apoptosis. ${ }^{191-193}$ When these become mutated or amplified they can overcome the normal restraints of cell growth. ${ }^{194,195}$ So-called 'tumour suppressor' genes can be involved in differentiation pathways that are coupled to cell growth, PTCH being a good example in point, and mutations or deletions of such genes have been reported in various types of cancer. ${ }^{196-198}$ However, mismatch repair genes are also classified as tumour suppressors and the functional distinction between oncogenes, proto-oncogenes and so-called tumour suppressors is blurring. A more useful distinction is that in general (proto-)oncogenes need to be activated, and tumour 'suppressor' genes inactivated for malignant transformation to occur. ${ }^{199}$ Defects in the latter appear to be more common than defects in oncogenes. $^{200}$ 'Mutator' or caretaker genes (involved in DNA repair) maintain the genome integrity and when their function is altered, mutations can accumulate more frequently. ${ }^{190}$

\section{Proliferation vs. differentiation in basal cell carcinoma}

Proliferation indices vary greatly for the different subtypes of $\mathrm{BCC}$, but in general relatively high percentages of proliferating tumour cells are found. ${ }^{201-204}$ Based on immunohistochemical detection of the proliferation marker Ki-67, an average of $20 \%$ of the cells in BCC are found to be proliferating. ${ }^{202,203,205,206}$ The proliferating cell nuclear antigen (PCNA) is present in $<10 \%$ of non-recurrent BCCs, while recurrent BCCs show PCNA expression in $>30 \%$ of the tumour cells. ${ }^{207,208}$ In nodular and superficial BCC the proliferative activity is mainly restricted to the periphery of the tumour nests, whereas morphea-like tumours show a more scattered pattern of proliferating cells. ${ }^{202},{ }^{206}$ An explanation for the zonal distribution of proliferation-potent cells may be that tumour cells migrating towards the centre of the tumour nests become more differentiated, or have less access to nutrients, resulting in lower proliferation potential. ${ }^{209}$ Alternatively, adhesive properties may determine both behaviours.

Markers for the arrest of cell proliferation include the A-type lamins, also sometimes known as statins. ${ }^{210}$ Nuclear lamins are intermediate filament proteins that form a network at the nucleoplasmic site of the nuclear membrane and can be divided in two subtypes, i.e. A-type lamins (lamin A, lamin $\mathrm{A} \Delta 10$ and lamin C) and B-type lamins (lamin B1 and lamin B2). ${ }^{211,212}$ Aberrant expression patterns of lamins have been described in cancer and it is thought that the nuclear matrix plays a role in carcinogenesis. ${ }^{213}$ In general, A-type lamin expression is correlated with a non-proliferating, differentiated state of cells and tissues, ${ }^{214}$ and therefore altered expression of A-type lamins can be expected in cancer. In BCC, it was recently reported by Venables et al. ${ }^{215}$ that the absence of lamin A correlated with rapid growth, while the absence of lamin C correlated with slow growth. Furthermore, it was reported that the expression of A- and B-type lamins varies with differentiation in normal epidermis ${ }^{216}$ and skin tumours. $^{216,217}$ These authors support the idea that expression of A-type lamins, but not B-type lamins is associated with the differentiation phenotype of the tumours. Recently, Tilli et al. ${ }^{218}$ reported four stages in BCC development based on different patterns of A-type lamin expression. Stage 1 comprises lamin A-negative, Ki-67-positive BCCs, representing the origin of $\mathrm{BCC}$, while stage 2 comprises lamin A-positive, Ki-67-positive BCCs. As tumour growth slows down, lamin C is first relocated to the nucleolus in stage 3 and in stage 4 lamin $\mathrm{C}$ expression is largely diminished.

The fact that BCC shows relatively high percentages of proliferating tumour cells is not in line with the clinical finding that BCC is usually a slow-growing tumour. ${ }^{219}$ Therefore, cell loss must be considered as an important factor in the net growth of BCC. Already in 1972, Kerr et al. ${ }^{220}$ reported that a high apoptotic rate in BCC might account for the seemingly paradoxically slow growth rate. Furthermore, Mooney et al. ${ }^{221}$ showed that BCCs do indeed exhibit a high apoptotic rate as based on in situ end-labelling of nicked DNA ends [using TUNEL staining, terminal deoxynucleotidyl transferase (TdT)mediated deoxyuridine triphosphate (dUTP) nick-end labelling].

\section{Apoptosis in epidermis and basal cell carcinoma}

Apoptosis, a form of programmed cell death, is characterized by cell shrinkage and fragmentation. ${ }^{222}$ Apoptosis is one process among others that is necessary for the correct development of an embryo, ${ }^{223}$ and to eliminate autoreactive lymphocytes. ${ }^{224}$ Abnormal, unwanted or damaged cells are removed by apoptosis without the involvement of the immune system, but through rapid phagocytosis of apoptotic cells before lysis, which prevents inflammation. ${ }^{225}$ In this 
respect the process of programmed cell death can be clearly distinguished form accidental cell death, i.e. necrosis.

During the different phases of apoptosis various sets of molecules act in an orchestrated fashion. These include:

1 Death ligands and death receptors. The family of death receptors is characterized by two to five copies of cysteine-rich extracellular repeats and a death domain within the intracellular carboxy-terminus of the receptor (the death domain). ${ }^{226}$ When these death receptors are bound by ligands, apoptosis can be induced. Fas is an example of a type I transmembrane receptor which mediates apoptosis upon binding of the oligomerizing Fas ligand (FasL). ${ }^{227}$ Fas is expressed on several different cell types, while expression of FasL is restricted to immune cells, including $\mathrm{T}$ and $\mathrm{B}$ lymphocytes, macrophages and natural killer cells. ${ }^{228,229}$ Ligation of FasL to Fas causes rapid death-inducing signalling complex formation, which recruits and activates pro-caspase-8, thus triggering the apoptotic caspase cascade (see below).

2 Bcl-2 protein family. Many studies concentrate on the Bcl-2 family of apoptosis-regulating proteins. ${ }^{230,231} \mathrm{Bcl}-2$ was first discovered in B-cell lymphomas showing a $\mathrm{t}(14: 18)$ translocation, ${ }^{232}$ resulting in a Bcl-2-immunoglobulin-heavy chain fusion gene. ${ }^{233}$ This leads to overexpression of the antiapoptotic Bcl-2 protein. The protein has been shown to suppress apoptosis induced by various stimuli, such as depletion of interleukin (IL)-3 and IL-4 ${ }^{234,235}$ p53-induced apoptosis, ${ }^{236}$ glucocorticoid treatment, ${ }^{237}$ and c-myc induced apoptosis. ${ }^{238} \mathrm{Bcl}-2$ expression has been localized to long-lived (stem) cells in self-renewing human tissues. ${ }^{191}$ The protein is associated with the membranes of mitochondria, endoplasmatic reticulum and nucleus, ${ }^{239}$ and bears seven phosphorylation sites of which ser70 is critical for the apoptosis-suppressing function of Bcl-2. ${ }^{240}$ A large number of Bcl-2-related proteins ${ }^{230,231,241,242}$ have been isolated, which can act either as apoptosis-inducing (e.g. Bax, Bcl-xs) or apoptosis-suppressing agents (Bcl-xl). Heterodimerization between these family members determines whether a cell will die or not. ${ }^{243,244}$

3 Caspases. The aspartate-specific cysteine protease (caspase) cascade appears to be the main pathway for clearance of cellular constituents during the execution phase of apoptosis. ${ }^{245}$ Several human caspases have been identified that share similarities in amino acid sequence, structure and substrate specificity. ${ }^{246,247}$ Caspases show a high specificity for the conserved QACXG sequence, resulting in the cleavage after aspartic acid (Asp) residues. ${ }^{248}$ The caspase family comprises apoptotic initiators (e.g. caspase-2, -8, -9 and -10) and apoptotic executioners (e.g. caspase-3, -6 and -7 ). ${ }^{246}$ Caspase- 3 seems to be responsible for the majority of apoptotic effects, and is supported by caspase- 6 and -7 . These three executioner caspases are important in the cleavage and degradation of several substrates, target proteins that are involved in RNA splicing, DNA repair, and scaffolding of the cytosol and the nucleus. Upon induction of apoptosis, caspase- 3 cleaves the inhibitor of the caspase-activated DNAse, resulting in degradation of DNA into oligonucleosomal fragments. ${ }^{249,250}$ Lamin A is cleaved by caspase- $6^{251,252}$ while in addition, cytoskeletal filaments such as cytokeratins are cleaved by caspase- $6 .{ }^{253}$ The externalization of phosphatidyl-serine at the cell membrane during apoptosis is also caspase-dependent. ${ }^{254}$ The nuclear matrix protein poly(ADP-ribose) polymerase is also proteolysed by caspases during apoptosis. ${ }^{255}$

Inhibitors of apoptosis proteins, which are constitutively present in cells, ${ }^{256,257}$ for example, bind to and inhibit caspase- 3 and -7 as well as pro-caspase- 9 , but not capase-1, $-6,-8$ or -10 .

When apoptosis occurs inappropriately it may cause degeneration of normal tissue architecture or function. On the other hand, when apoptosis fails to occur this can give rise to dysregulation of tissue homeostasis, as a result of which neoplasms can arise.

Apoptosis in the epidermis is a common phenomenon. In the morphogenesis of human fetal skin and maintenance of adult epidermis apoptosis plays a pivotal role. ${ }^{258}$ For example, the apoptosis machinery is activated during the normal terminal differentiation process in keratinocytes. ${ }^{259}$ In fetal skin, cells undergoing apoptosis are present in several epidermal cell layers, whereas in neonatal epidermis these are found in the terminally differentiating granular cell layer, and in adult skin the spinous cells also show occasional apoptosis. ${ }^{258}$ Furthermore, apoptosis occurs upon excessive UV light exposure, resulting in irreparable DNA damage (see also Fig. 2). ${ }^{260} \mathrm{~A}$ significant negative correlation between the expression of either p53 or bcl-2 with the development of BCC has been described previously. ${ }^{261}$ Mutation of p53 or overexpression of bcl-2 is sufficient to enhance the formation of BCC by suppressing apoptosis. ${ }^{262,263}$

Altered expression of Bcl-2 family member proteins in nonmelanoma skin cancer has been reported extensively before, ${ }^{264}$ suggesting that dysregulation of expression of these proteins may be a possible explanation of the indolent growth behaviour of $\mathrm{BCC}^{206,265} \mathrm{Bcl}-2$ is in general homogeneously expressed in BCC, ${ }^{206,266-268}$ while the apoptosis-inducing Bax protein is also expressed at high levels. ${ }^{206,264}$ These data clearly show that a considerable proportion of cells in BCC are in principle capable of undergoing apoptosis, corroborating the earlier findings of Mooney et al. ${ }^{221}$

Another apoptosis-inhibitor protein called survivin is expressed in $81 \%$ of BCCs, whereas it is not detected in normal skin, suggesting a contribution to the progression of BCC. $^{269}$

Also, Fas-mediated apoptosis may be important for skin homeostasis. Hill et al. ${ }^{270}$ suggested that dysregulation of Fas-FasL interactions may be central to the development of skin cancer. In normal skin, Fas is expressed in cytoplasmic membranes of the basal cell layer, while after sun exposure the expression of Fas is up-regulated in the entire epidermis. After further UV exposure, Fas expression is again down-regulated, resulting in negative staining in BCC. ${ }^{271}$ BCCs express FasL, however, strongly and diffusely, providing evidence for an escape from local immunesurveillance by the induction of apoptosis in the peripheral $\mathrm{T}$ lymphocytes. ${ }^{272}$ 


\section{Current and future therapeutic modalities - from surgical to biological}

Various surgical and non-surgical therapies are available for the treatment of $\mathrm{BCC}{ }^{273}$ Medical history of the patient, age, tumour localization and size, physical condition, histological outcomes and cosmetic aspects will eventually determine the choice of therapy. Furthermore, Telfer et al. ${ }^{274}$ published guidelines for the management of $\mathrm{BCC}$, presenting evidence-based guidance for treatment. In spite of the fact that surgical excision is still the most prominent therapy used, non-invasive therapies such as photodynamic therapy $(\mathrm{PDT})^{275}$ or topical application of 5-fluorouracil $(5-\mathrm{FU})^{276}$ are currently becoming more and more interesting in selective cases, especially because of the improved cosmetic outcome.

\section{Surgery}

Throughout this review we have used the term 'basal cell carcinoma' instead of 'basalioma', in keeping with current practice in the Netherlands. 'Carcinoma' suggests malignancy as well as full metastatic potential. Dermatological surgeons treat $\mathrm{BCC}$ as such and justify mutilating procedures by referring to the presumed malignant nature of the lesion, dreading recurrence as if it were melanoma. While definitely capable of causing local tissue destruction if left untreated, BCCs rarely, if ever, metastasize. Hence one may wonder whether it is really necessary to eradicate every last trace of tumour surgically. A recurrence often can be quite easily treated and will follow only about $1 \cdot 6-5 \%$ of conventional excisions aimed at free margins (a procedure that can leave undetected residual cells, particularly in the morpheaform growth type). ${ }^{277,278}$ As discussed below, biological therapies offer great promise and may be used as adjuvants to conventional excision, allowing for more conservative surgery in the future.

\section{Induction of apoptosis}

Many currently used antineoplastic agents exert their therapeutic effects through the induction of apoptosis. Different cell types vary profoundly in their susceptibility, suggesting the existence of distinct cellular thresholds for apoptosis induction. ${ }^{279}$ For example, BCC cells overexpressing IL-6 are resistant to UV irradiation and PDT-induced apoptosis. ${ }^{280}$ Furthermore, it was shown that de novo p53 synthesis or stabilization of p53 is essential to induce apoptosis in BCC. ${ }^{281}$ Overexpression of the antiapoptotic Bcl-2 has also been linked to resistance of cancers to various chemotherapeutic drugs. ${ }^{282}$ In BCC, interferon (IFN)- $\alpha$ induces apoptosis and is thus effective in the treatment. ${ }^{283}$ Untreated BCC cells express FasL but not the receptor, but in IFN- $\boldsymbol{\alpha}$-treated BCC patients the tumour cells express both FasL and receptor, whereas the peritumoral infiltrate mainly consists of Fas-receptor-positive cells. ${ }^{284}$ Therefore, with IFN- $\alpha$ treatment, BCC most likely regresses through apoptosis.
Topical treatment of BCC with 5-FU has also been proven to be very successful. Up to $90 \%$ of treated BCCs show regression when 5-FU is applied in a phosphatidyl cholinebased cream ${ }^{285}$ or when it is locally injected in an epinephrine-containing gel. ${ }^{276}$ The regression of tumours treated with 5 -FU is probably caused by enhancing apoptosis in the tumour cells. ${ }^{286}$ Recently, Nakaseko et al. ${ }^{287}$ reported that apoptosis is involved in regression of the lesion after PDT in actinic keratosis. This therapy is also used for treatment of $\mathrm{BCC}^{288}$ where tumour cells may also undergo apoptosis.

Phytochemicals known to induce apoptosis are also being applied in cancer prevention and therapy. ${ }^{289}$ Recently, Levin and Maibach ${ }^{290}$ published an overview of plant-derived drugs and treatments in dermatology. It was shown that application of green tea polyphenolic fractions reduced UVinduced erythema, gave rise to a decrease in sunburns and could also reduce the number of UV-induced mutations in DNA. $^{291}$ Oral and topical application of black tea extracts also decreased photochemical damage to the skin. ${ }^{292}$ Furthermore, in mice bearing skin tumours, tumour growth was inhibited by $70 \%$ after treatment with black tea, which was established by inhibition of proliferation and enhanced apoptosis. $^{293}$ Ajoene, an organosulphur compound of garlic, ${ }^{294}$ has been shown to induce apoptosis in human promyeloleukaemic cells. ${ }^{295}$ Recently, it was shown that ajoene can induce apoptosis in the human keratinocyte cell line $\mathrm{HaCat}$ and has a diminishing effect on $\mathrm{BCC}$ in vivo by down-regulating the expression of the apoptosis-suppressing protein Bcl-2. ${ }^{296}$ Apart from the induction of apoptosis by directly targeting its mediators, the obvious role of the $\mathrm{SHH}$ pathway in BCC growth suggests that interference with this pathway may also be used to treat BCC. Indeed, it was recently shown that a $\mathrm{SHH}$ antagonist, the Veratrum alkaloid cyclopamine (11-deoxojervine) can be used to treat BCC. ${ }^{297}$ Cyclopamine binds directly to Smoothened, which explains its activity in tumours characterized by activated SHH pathways. ${ }^{298}$ Interestingly, its application to the surface of the tumour resulted not only in the rapid induction of apoptosis but also influenced the differentiation status in seven of seven tumours. ${ }^{299}$

\section{Modulation of differentiation}

Retinoids (vitamin A metabolites and analogues) have also been shown to have suppressive effects on tumour promotion when administered in high doses, and the mechanism appears to be associated with modulation of growth, differentiation and apoptosis. ${ }^{300}$ However, clinical experience suggests that the antitumour activity of retinoids when administered in tolerable doses is limited as a result of adaptation of the tumour's retinoid metabolism. ${ }^{301}$ Retinoic acid metabolism blocking agents (RAMBAs) such as liarozole, possibly combined with retinoids in a relatively low dose, may offer a more tolerable and effective means of slowing tumour progression. $^{301,302}$ 


\section{Immunomodulation}

Because BCCs often elicit a strong inflammatory response, recent studies have sought to evaluate the effect of immunomodulatory compounds. One of the most promising is imiquimod, a Toll-like receptor $7 / 8$ agonist that enhances the endogenous cytokine response (among others, INF- $\alpha$, IL-10), stimulating the T-helper 1-mediated inflammatory responses. Several recent studies suggest that imiquimod can be used as a monotherapy, with excellent complete response rates $(80 \%$ and more). ${ }^{303-306}$ The tumours are infiltrated by macrophages and show an extensive apoptotic response.

\section{Conclusion}

In order to develop better pharmacological treatments for BCC, we need to understand its biological nature. As long as it is considered a malignancy, radical surgery seems to be justified, in particular for tumours with a morpheaform growth pattern. Hence the crucial question is whether BCC is truly cancer. If we are defining cancer as a clonal expansion of cells that are no longer under host control, and are not subject to replicative senescence and apoptosis, BCC is true cancer. On the other hand, the lack of defects in the control of genomic integrity and the apparent inability to metastasize seem to suggest that there are fundamental differences between BCC and other malignancies. For example, there seems to be an important difference between frank malignancies and BCC with regard to the timing of the activation of the SHH pathway in the process of tumorigenesis. In many tumour types, such as those of the lung or the pancreatic duct, the SHH route has to be reactivated since it is not normally active in those tissues during adult life but only during embryogenesis. In the normal adult hair follicle on the other hand, the SHH pathway is subject to cyclic activation. ${ }^{307}$ Hence, aberrations in this constitutional activity of the SHH pathway in the hair follicle may be initiating events in BCC tumorigenesis. ${ }^{308}$ In other tumours, on the other hand, SHH activation seems to contribute to tumour progression rather than to initiation. In view of the foregoing, it is our opinion that the designation 'basalioma' is most appropriate, because it emphasizes the proliferative nature of the disorder, and at the same time indicates the limited malignant potential.

The availability of proapoptotic and immunomodulatory compounds for the treatment of BCC may change therapy in the near future. For the majority of patients, surgery may no longer be the first treatment option. Tumours that are currently resected with a wide margin, a procedure that can result in mutilating defects, might be treated by limited primary excision followed by adjuvant therapy using an immunomodulator, a proapoptotic agent and/or a cell-signalling modulator.

\section{References}

1 Jacob A. Observations respecting an ulcer of peculiar character, which attacks the eyelids and other parts of the face. Dublin Hospital Rep 1824; 4:232-9.
2 Marks R. An overview of skin cancers: incidence and causation. Cancer 1995; 75:607-12.

3 Gloster HM, Brodland DG. The epidemiology of skin cancer. Dermatol Surg 1996; 22:217-26.

4 Leffell DJ, Headington JT, Wong DS et al. Aggressive growth basal cell carcinoma in young adults. Arch Dermatol 1991; 127:1663-7.

5 von Domarus HV, Stevens PJ. Metastatic basal cell carcinoma: report of five cases and review of 170 cases in the literature. J Am Acad Dermatol 1984; 10:1043-60.

6 Lo JS, Snow SN, Reizner GT. Metastatic basal cell carcinoma: report of twelve cases with a review of the literature. J Am Acad Dermatol 1991; 24:715-9.

7 Tavin E, Persky MS, Jacobs J. Metastatic basal cell carcinoma of the head and neck. Laryngoscope 1995; 105:814-17.

8 Wade TR, Ackerman AB. The many faces of basal cell carcinoma. J Dermatol Surg Oncol 1978; 4:778-80.

9 Rippey JJ. Why classify basal cell carcinomas? Histopathology 1998; 32:393-8.

10 Sexton M, Jones DB, Maloney ME. Histologic pattern analysis of basal cell carcinoma. J Am Acad Dermatol 1990; 23:1118-26.

11 Miller SJ. Biology of basal cell carcinoma (Part 1). J Am Acad Dermatol 1991; 24:1-13.

12 Jacobs GH, Rippey JJ, Altini M. Prediction of aggressive behaviour in basal cell carcinoma. Cancer 1982; 49:533-7.

13 Silverstone H, Gordon D. Regional studies in skin cancer. 2. Wet tropical and subtropical coasts of Queensland. Med J Aust 1996; 2:733-40.

14 Gallagher RP, Hill GB, Bajdik CD et al. Sunlight exposure, pigmentary factors, and risk of nonmelanocytic skin cancer. I. Basal cell carcinoma. Arch Dermatol 1995; 131:157-63.

15 Mithoefer AB, Supran S, Freeman RB. Risk factors associated with the development of skin cancer after liver transplantation. Liver Transpl 2002; 8:939-44.

16 Corona R, Dogliotti E, D’Errico M et al. Risk factors for basal cell carcinoma in a Mediterranean population: role of recreational sun exposure early in life. Arch Dermatol 2001; 137:1162-8.

17 Lear JT, Smith AG, Strange RD, Fryer AA. Patients with truncal basal cell carcinoma represent a high-risk group. Arch Dermatol 1998; 134:373.

18 Grossman D, Leffell DJ. The molecular basis of nonmelanoma skin cancer: new understanding. Arch Dermatol 1997; 133:1263-70.

19 Gallagher RP, Bajdik CD, Fincham S et al. Chemical exposures, medical history, and risk of squamous and basal cell carcinoma of the skin. Cancer Epidemiol Biomarkers Prev 1996; 5:419-24.

20 Diepgen TL, Mahler V. The epidemiology of skin cancer. Br J Dermatol 2002; 146 (Suppl. 61): 1-6.

21 de Hertog SA, Wensveen CA, Bastiaens MT et al. Relation between smoking and skin cancer. J Clin Oncol 2001; 19:231-8.

22 Boyd AS, Shyr Y, King LE Jr. Basal cell carcinoma in young women: an evaluation of the association of tanning bed use and smoking. J Am Acad Dermatol 2001; 46:706-9.

23 Stern RS. Carcinogenic risk of psoralen plus ultraviolet radiation therapy: evidence in humans. Natl Cancer Inst Monogr 1984; 66:211-6.

24 Katz KA, Marcil I, Stern RS. Incidence and risk factors associated with a second squamous cell carcinoma or basal cell carcinoma in psoralen + ultraviolet a light-treated psoriasis patients. J Invest Dermatol 2002; 118:1038-43.

25 Lindelof B, Sigurgeirsson B, Tegner E et al. PUVA and cancer: a large-scale epidemiological study. Lancet 1991; 338:91-3.

26 Stern RS, Laird N. The carcinogenic risk of treatments for severe psoriasis. Photochemotherapy Follow-Up Study. Cancer 1994; 73:2759-64. 
27 Stern RS. PUVA Follow-up Study. The risk of melanoma in association with long-term exposure to PUVA. J Am Acad Dermatol 2001; 44:755-61.

28 Barr BBB, McLaren K, Smith IW et al. Human papilloma virus infection and skin cancer in renal allograft recipients. Lancet 1989; 1:124-9.

29 Pfister H, Ter Schegget J. Role of HPV in cutaneous premalignant and malignant tumors. Clin Dermatol 1997; 15:335-47.

30 Weinstock MA, Coulter S, Bates J et al. Human papillomavirus and widespread cutaneous carcinoma after PUVA photochemotherapy. Arch Dermatol 1995; 131:701-4.

31 Harwood CA, Proby CM. Human papillomaviruses and non-melanoma skin cancer. Curr Opin Infect Dis 2002; 15:101-14.

32 Lear JT, Smith AG, Heagerty AHM et al. Truncal site and detoxifying enzyme polymorphisms significantly reduce time to presentation of further primary cutaneous basal cell carcinoma. Carcinogenesis 1997; 18:1499-503.

33 Strange RC, Spiteri MA, Ramachandran S et al. Glutathione S-transferase family of enzymes. Mutat Res 2001; 482:21-6.

34 Griffiths HR, Mistry P, Herbert KE et al. Molecular and cellular effect of ultraviolet light-induced genotoxicity. Crit Rev Clin Lab Sci 1998; 35:189-237

35 Ketterer B, Meyer DJ. Glutathione S-transferases: a possible role in the detoxification and repair of DNA and lipid hydroperoxides. Mutat Res 1989; 214:33-40.

36 Hayes JD, Pulford DJ. The glutathione S-transferase supergene family: regulation of GST and the contribution of the enzyme to cancer chemoprotection and drug resistance. Crit Rev Biochem Mol Biol 1995; 30:445-600

37 Raza H, Awasthi YC, Zaim MT et al. Glutathione S-transferases in human and rodent skin: multiple forms and species-specific expression. J Invest Dermatol 1991; 96:463-7.

38 Moscow JA, Townsend AJ, Goldsmith ME et al. Isolation of the human anionic glutathione S-transferase cDNA and the relation of its gene expression to estrogen-receptor content in primary breast cancer. Proc Natl Acad Sci USA 1998; 85:6518-22.

39 Henderson CJ, Smith AG, Ure J et al. Increased skin tumorigenesis in mice lacking pi class glutathione S-transferases. Proc Natl Acad Sci USA 1998; 95:5275-80

40 Schadendorf D, Jurgovsky K, Kohlmus CM, Czarnetzki BM. Glutathione and related enzymes in tumor progression and metastases of human melanoma. J Invest Dermatol 1995; 105:109-12.

41 Hanada K, Ishikawa H, Tamai K et al. Expression of glutathione S-transferase-pi in malignant skin tumors. J Dermatol Sci 1991; 2:18-23.

42 Pemble S, Schroeder KR, Spencer SR et al. Human glutathione S-transferase theta (GSTT1): cDNA cloning and the characterization of a genetic polymorphism. Biochem J 1994; 300:271-6.

43 Heagerty AHM, Fitzgerald D, Smith A et al. Glutathione S-transferase GSTM1 phenotypes and protection against cutaneous malignancy. Lancet 1994; 343:266-8.

44 Heagerty A, Smith A, English J et al. Susceptibility to multiple cutaneous basal cell carcinomas: significant interaction between glutathione S-transferase GSTM1 genotypes, skin type and male gender. Br J Cancer 1996; 73:44-8.

45 Kerb R, Brockmoller J, Reum T, Roots I. Deficiency of glutathione S-transferases $\mathrm{T} 1$ and $\mathrm{M} 1$ as heritable factors of increased cutaneous UV sensitivity. J Invest Dermatol 1997; 108:229-32.

46 Lear JT, Heagerty AHM, Smith A et al. Multiple cutaneous basal cell carcinomas: glutathione S-transferase (GSTM1, GSTT1) and cytochrome P450 (CYP2D6, CYP1A1) polymorphisms influence tumour numbers and accrual. Carcinogenesis 1996; 17:1891-6.
47 Yengi L, Inskip A, Gilford J et al. Polymorphism at the glutathione S-transferase locus GSTM3: interactions with cytochrome P450 and glutathione S-transferase genotypes as risk factors for multiple cutaneous basal cell carcinoma. Canc Res 1996; 56:1974- 7.

48 Ramachandran S, Fryer AA, Smith AG et al. Basal cell carcinomas: association of allelic variants with a high-risk subgroup of patients with the multiple presentation phenotype. Pharmacogenetics 2001; 11:247-54.

49 Ramachandran S, Lear JT, Ramsay H et al. Presentation with multiple cutaneous basal cell carcinomas: association of glutathione S-transferase and cytochrome P450 genotypes with clinical phenotype. Cancer Epidemiol Biomarkers Prev 1999; 8:61-7.

50 Ramachandran S, Hoban PR, Ichii-Jones F et al. Glutathione S-transferase GSTP1 and cyclin D1 genotypes: association with numbers of basal cell carcinomas in a patient subgroup at highrisk of multiple tumors. Pharmacogenetics 2000; 10:545-56.

51 Milstone EB, Helwig EB. Basal cell carcinoma in children. Arch Dermatol 1973; 108:523-7.

52 Cleaver JE. Defective repair replication of DNA in xeroderma pigmentosum. Nature 1968; 218:652-6.

53 Sarasin A. The molecular pathways of ultraviolet-induced carcinogenesis. Mutat Res 1999; 428:5-10.

54 Cleaver JE. Ultraviolet photobiology: its early roots and insights into DNA repair. DNA Repair (Amst) 2002; 1:977-9.

55 Hoeijmakers JH. Genome maintenance mechanisms for preventing cancer. Nature 2001; 411:366-74.

56 Yu CE, Oshima J, Fu YH et al. Positional cloning of the Werner's syndrome gene. Science 1996; 272:193-4.

57 Ellis NA, Groden J, Ye TZ et al. The Bloom's syndrome gene product is homologous to RecQ helicases. Cell 1995; 83:655-66.

58 Kitao S, Shimamoto A, Goto $M$ et al. Mutations in RECQL4 cause a subset of cases of Rothmund-Thomson syndrome. Nat Genet 1999; 22:82-4

59 Wang LL, Levy ML, Lewis RA et al. Clinical manifestations in a cohort of 41 Rothmund-Thomson syndrome patients. Am J Med Genet 2001; 102:11-17.

60 Malkin D, Li FP, Strong LC et al. Germ line p53 mutations in a familial syndrome of breast cancer, sarcomas, and other neoplasms. Science 1990; 250:1233-8.

61 Knight SW, Heiss NS, Vulliamy TJ et al. X-linked dyskeratosis congenita is predominantly caused by missense mutations in the DKC1 gene. Am J Hum Genet 1999; 65:50-8.

62 Vulliamy T, Marrone A, Goldman F et al. The RNA component of telomerase is mutated in autosomal dominant dyskeratosis congenita. Nature 2001; 413:432-5.

63 Katayama H, Brinkley WR, Sen S. The Aurora kinases: role in cell transformation and tumorigenesis. Cancer Metastasis Rev 2003; 22:451-64.

64 Gorlin RJ. Nevoid basal cell carcinoma syndrome. Dermatol Clin 1995; 13:113-25.

65 Harris CC. Molecular epidemiology of basal cell carcinoma. J Natl Cancer Inst 1996; 88:315-17.

66 Hahn H, Wicking C, Zaphiropoulous PG et al. Mutation of the human homolog of Drosophila patched in the nevoid basal cell carcinoma syndrome. Cell 1996; 85:841-51.

67 Johnson RL, Rothman AL, Xie J et al. Human homolog of patched, a candidate gene for the basal cell nevus syndrome. Science 1996; 272:1668-71.

68 Wicking C, McGlinn E. The role of hedgehog signalling in tumorigenesis. Cancer Lett 2001; 173:1-7.

69 Kim M-Y, Park HJ, Baek S-C et al. Mutations of the p53 and PTCH gene in basal cell carcinomas: UV mutation signature and strand bias. J Dermatol Sci 2002; 29:1-9. 
70 Bodak N, Queille S, Avril MF et al. High levels of patched gene mutations in basal cell carcinomas from patients with xeroderma pigmentosum. Proc Natl Acad Sci USA 1999; 96:5117-22.

71 Bale AE, Yu K-P. The hedgehog pathway and basal cell carcinomas. Hum Mol Genet 2001; 10:757-62.

72 Wicking C, Smyth I, Bale A. The hedgehog signalling pathway in tumorigenesis and development. Oncogene 1999; 18:7844-51.

73 Echelard Y, Epstein DJ, St-Jacques B et al. Sonic hedgehog, a member of a family of putative signaling molecules, is implicated in the regulation of CNS polarity. Cell 1993; 75:1417-30.

74 Johnson RL, Laufer E, Riddle RD et al. Ectopic expression of Sonic hedgehog alters dorsal-ventral patterning of somites. Cell 1994; 79:1165-73.

75 Riddle RD, Johnson RL, Laufer E et al. Sonic hedgehog mediates the polarizing activity of the ZPA. Cell 1993; 75:1401-16.

76 Stone DM, Hynes M, Armanini M et al. The tumour-suppressor gene patched encodes a candidate receptor for Sonic hedgehog. Nature 1996; 384:129-34.

77 Taipale J, Cooper MK, Maiti T et al. Patched acts catalytically to suppress the activity of Smoothened. Nature 2002; 418:892-7.

78 Sprong H. van der Sluijs P, van Meer G. How proteins move lipids and lipids move proteins. Nat Rev Mol Cell Biol 2001; 2:50413.

79 Stone DM, Murone M, Luoh S et al. Characterization of the human suppressor of fused, a negative regulator of the zinc-finger transcription factor Gli. J Cell Sci 1999; 112:4437-48.

80 Cohen MM Jr, The hedgehog signaling network. Am J Med Genet 2003; 123A:5-28.

81 Jamora C, DasGupta R, Kocieniewski P et al. Links between signal transduction, transcription and adhesion in epithelial bud development. Nature 2003; 422:317-22.

82 Chan EF, Gat U, McNiff JM et al. A common human skin tumour is caused by activating mutations in beta-catenin. Nat Genet 1999; 21:410-13.

83 Chan EF. Pilomatricomas contain activating mutations in betacatenin. J Am Acad Dermatol 2000; 43:701-2.

$84 \mathrm{Lam} \mathrm{CW}$, Xie J, To KF et al. A frequent activated smoothened mutation in sporadic basal cell carcinomas. Oncogene 1999; 18:833-6.

85 Aszterbaum M, Epstein J, Oro A et al. Ultraviolet and ionizing radiation enhance the growth of BCCs and trichoblastomas in patched heterozygous knockout mice. Nat Med 1999; 5:1285-91.

86 Xie J, Murone M, Luoh SM et al. Activating Smoothened mutations in sporadic basal cell carcinomas. Nature 1998; 391:90-2.

87 Daya-Grosjean L, Sarasin A. UV-specific mutations of the human patched gene in basal cell carcinomas from normal individuals and xeroderma pigmentosum patients. Mut Res 2000; 450:193-9.

88 Gailani MR, Stahle-Backdahl M, Leffell DJ et al. The role of the human homologue of Drosophila patched in sporadic basal cell carcinoma. Nat Genet 1996; 14:78-81.

89 Zaphiropoulos PG, Unden AB, Rahnama F et al. PTCH2, a novel human patched gene, undergoing alternative splicing and upregulate in basal cell carcinoma. Cancer Res 1999; 59:787-92.

90 Smyth I, Narang MA, Evans T et al. Isolation and characterization of human patched 2 ( $\mathrm{PTCH} 2$ ), a putative tumour suppressor gene in basal cell carcinoma and medulloblatoma on chromosome 1p32. Hum Mol Genet 1999; 8:291-7.

91 Kovalenko A, Chable-Bessia C, Cantarella G et al. The tumour suppressor CYLD negatively regulates NF-kappaB signalling by deubiquitination. Nature 2003; 424:801-5.

92 Brummelkamp TR, Nijman SM, Dirac AM et al. Loss of the cylindromatosis tumour suppressor inhibits apoptosis by activating NF-kappaB. Nature 2003; 424:797-801.
93 Trompouki E, Hatzivassiliou E, Tsichritzis T et al. CYLD is a deubiquitinating enzyme that negatively regulates NF-kappaB activation by TNFR family members. Nature 2003; 424:793-6.

94 Yan M, Wang LC, Hymowitz SG et al. Two-amino acid molecular switch in an epithelial morphogen that regulates binding to two distinct receptors. Science 2000; 290:523-7.

95 Sinha SK, Zachariah S, Quinones HI et al. Role of TRAF3 and -6 in the activation of the NF-kappa B and JNK pathways by X-linked ectodermal dysplasia receptor. J Biol Chem 2002; 277:44953-61.

96 Yan M, Zhang Z, Brady JR et al. Identification of a novel death domain-containing adaptor molecule for ectodysplasin-A receptor that is mutated in crinkled mice. Curr Biol 2002; 12:409-13.

97 Kumar A, Eby MT, Sinha S et al. The ectodermal dysplasia receptor activates the nuclear factor-kappaB, JNK, and cell death pathways and binds to ectodysplasin A. J Biol Chem 2001; 276:2668-77.

98 Kere J, Srivastava AK, Montonen O et al. X-linked anhidrotic (hypohidrotic) ectodermal dysplasia is caused by mutation in a novel transmembrane protein. Nat Genet 1996; 13:409-16.

99 Headon DJ, Emmal SA, Ferguson BM et al. Gene defect in ectodermal dysplasia implicates a death domain adapter in development. Nature 2001; 414:913-6.

100 Naito A, Yoshida H, Nishioka E et al. TRAF6-deficient mice display hypohidrotic ectodermal dysplasia. Proc Natl Acad Sci USA 2002; 99:8766-71.

101 Shindo M, Chaudhary PM. The ectodermal dysplasia receptor represses the Lef-1/beta-catenin-dependent transcription independent of NF-kappaB activation. Biochem Biophys Res Commun 2004; 315:73-8.

102 Novak U, Cocks BG, Hamilton JA. A labile repressor acts through the NFkB-like binding sites of the human urokinase gene. Nucl Acids Res 1991; 19:3389-93.

103 Bettencourt MS, Prieto VG, Shea CR. Trichoepithelioma a 19-year clinicopathologic re-evaluation. J Cutan Pathol 1999; 26:398-404.

104 Michaelsson G, Olsson E, Westermark P. The Rombo syndrome: a familial disorder with vermiculate atrophoderma, milia, hypotrichosis, trichoepitheliomas, basal cell carcinomas and peripheral vasodilation with cyanosis. Acta Derm Venereol (Stockh) 1981; 61:497-503.

105 van Steensel MA, Jaspers NG, Steijlen PM. A case of Rombo syndrome. Br J Dermatol 2001; 144:1215-8.

106 Vabres P, Lacombe D, Rabinowitz LG et al. The gene for BazexDupre-Christol syndrome maps to chromosome Xq. J Invest Dermatol 1995; 105:87-91.

107 Kastan MB, Onkyekwere O, Sidransky D et al. Participation of p53 protein in the cellular response to DNA damage. Cancer Res 1991; 51:6304-11.

108 Katayama H, Sasai K, Kawai H et al. Phosphorylation by aurora kinase A induces Mdm2-mediated destabilization and inhibition of p53. Nat Genet 2004; 36:55-62.

109 Hollstein M, Sidransky D, Vogelstein B et al. p53 mutations in human cancers. Science 1991; 253:49-53.

110 Siliciano JD, Canman CE, Taya Y et al. DNA damage induces phosphorylation of the amino terminus of p53. Genes Dev 1997; 11:3471-81.

111 Caspari T. How to activate p53. Curr Biol 2000; 10:315-7.

112 Kubbutat MHG, Jones SN, Vousden KH. Regulation of p53 stability by Mdm2. Nature 1997; 387:299-303.

113 Haupt Y, Maya R, Kazaz AN et al. Mdm2 promotes the rapid degradation of p53. Nature 1997; 387:296-9.

114 Unger T, Juven-Gershon T, Moallem E et al. Critical role for Ser20 of human $\mathrm{p} 53$ in the negative regulation of $\mathrm{p} 53$ by Mdm2. EMBO J 1999; 18:1805-14. 
115 Vogt Sionov RV, Haupt Y. The cellular response to p53: the decision between life and death. Oncogene 1999; 18:6145-57.

116 Ronen D, Schwartz D, Teitz Y et al. Induction of HL-60 cells to undergo apoptosis is determined by high levels of wild-type p53 protein whereas differentiation of the cells is mediated by lower p53 levels. Cell Growth Different 1996; 7:21-30.

117 Miyashita T, Reed JC. Tumour suppressor p53 is a direct transcriptional activator of the human bax gene. Cell 1995; 80:2939.

118 Merchant AK, Loney TL, Maybaum J. Expression of wild-type p53 stimulates an increase in both bax and bcl-xl protein content in HT-29 cells. Oncogene 1996; 13:2631-7.

119 Hall PA, McKee PH, Dover R et al. High levels of p53 protein in UV-irradiated normal human skin. Oncogene 1993; 8:203-7.

120 Auepemkiate S, Boonyaphiphat P, Thongsuksai P. P53 expression related to the aggressive infiltrative histopathological feature of basal cell carcinoma. Histopathology 2002; 40:568-73.

121 Demirkan NC, Colakoglu N, Duzcan E. Value of p53 protein in biological behavior of basal cell carcinoma and in normal epithelia adjacent to carcinomas. Pathol Oncol Res 2000; 6:272-4.

122 Fukasawa $\mathrm{K}$, Choi $\mathrm{T}$, Kuriyama $\mathrm{R}$ et al. Abnormal centrosome amplification in the absence of p53. Science 1996; 271:1744- 7 .

123 Pritchard BN, Youngberg GA. Atypical mitotic figures in basal cell carcinoma. A review of 208 cases. Am J Dermatopathol 1993; 15:549-52.

124 Rosenstein BS, Phelps RG, Weinstock MA et al. p53 mutations in basal cell carcinomas arising in routine users of sunscreen. Photochem Photobiol 1999; 70:798-806.

125 Ziegler A, Leffell DJ, Kunala S et al. Mutation hotspots due to sunlight in the p53 gene of nonmelanoma skin cancers. Proc Natl Acad Sci USA 1993; 90:4216-20.

126 Knudson AGJ. Hereditary cancer, oncogenes and antioncogenes. Cancer Res 1985; 45:1437-43.

127 Wikonkal NM, Brash DE. Ultraviolet radiation induced signature mutations in photocarcinogenesis. J Invest Dermatol Symp Proc 1999; 4:6-10.

128 Parsa R, Yang A, McKeon F et al. Association of p63 with proliferative potential in normal and neoplastic human keratinocytes. J Invest Dermatol 1999; 113:1099-105.

129 Wang TY, Chen BF, Yang YC et al. Histologic and immunophenotypic classification of cervical carcinomas by expression of the p53 homologue p63: a study of 250 cases. Hum Pathol 2001; 32:479-86.

130 Quade BJ, Yang A, Wang Y et al. Expression of the p53 homologue p63 in early cervical neoplasia. Gynecol Oncol 2001; 80: 24-9.

131 Di Como CJ, Urist MJ, Babayan I et al. p63 expression profiles in human normal and tumor tissues. Clin Cancer Res 2002; 8:494501.

132 Mills AA, Zheng B, Wang XJ et al. P63 is a p53 homologue required for limb and epidermal morphogenesis. Nature 1999; 398:708-13.

133 Osada M, Ohba C, Kawahara C et al. Cloning and functional analysis of human p51, which structurally and functionally resembles p53. Nat Med 1998; 4:839-43.

134 Little NA, Jochemsen AG. Molecules in focus: p63. Int J Biochem Cell Biol 2002; 34:6-9.

135 Pellegrini G, Dellambra E, Golisano O et al. P63 identifies keratinocyte stem cells. Proc Natl Acad Sci USA 2001; 98:3156-61.

136 Koster MI, Huntzinger KA, Roop DR. Epidermal differentiation: transgenic/knockout mouse models reveal genes involved in stem cell fate decisions and commitment to differentiation. J Invest Dermatol Symp Proc 2002; 7:41-5.
137 Dellavalle RP, Walsh P, Marchbank A et al. CUSP/p63 expression in basal cell carcinoma. Exp Dermatol 2002; 11:203-8.

138 Liefer KM, Koster MI, Wang XJ et al. Down-regulation of p63 is required for epidermal UV-B-induced apoptosis. Cancer Res 2000; 60:4016-20.

139 Penn I. Effect of immunosuppression on pre-existing cancers. Transplantation 1993; 55:742-7.

140 Espana A, Redondo P, Fernandez AL et al. Skin cancer in heart transplant recipients. J Am Acad Dermatol 1995; 32:458-65.

141 Ferrandiz C, Fuente MJ, Ribera M et al. Epidermal dysplasia and neoplasia in kidney transplant recipients. J Am Acad Dermatol 1995; 33:590-6.

142 Otley CC, Pittelkow MR. Skin cancer in liver transplant recipients. Liver Transpl 2000; 6:253-62.

143 Ondrus D, Pribylincova V, Breza J et al. The incidence of tumors in renal transplant recipients with long-term immunosuppressive therapy. Int Urol Nephrol 1999; 31:417-22.

144 Barrett WI, First MR, Aron BS, Penn I. Clinical course of malignancies in renal transplant recipients. Cancer 1993; 72:2186-9.

145 Ong CS, Keogh AM, Kossard S et al. Skin cancer in Australian heart transplant recipients. J Am Acad Dermatol 1999; 40:27-34.

146 Hartevelt MM, Bouwes Bavinck JN, Kootte AMM et al. Incidence of skin cancer after renal transplantation in The Netherlands. Transplantation 1990; 49:506-9.

147 Euvrard S, Kanitakis J, Pouteil-Noble C et al. Comparative epidemiologic study of premalignant and malignant epithelial cutaneous lesions developing after kidney and heart transplantation. J Am Acad Dermatol 1995; 33:222-9.

148 de Berker D, Ibbotson S, Simpson NB et al. Reduced experimental contact sensitivity in squamous cell but not basal cell carcinomas of skin. Lancet 1995; 345:425-6.

149 Franceschi S, Dal Maso L, Arniani S et al. Risk of cancer other than Kaposi's sarcoma and non-Hodgkin's lymphoma in persons with AIDS in Italy. Cancer AIDS Registry Linkage Study. Br J Cancer 1998; 78:966-70.

150 Ragni MV, Belle SH, Jaffe RA et al. Acquired immunodeficiency syndrome-associated non-Hodgkin's lymphomas and other malignancies in patients with hemophilia. Blood 1993; 81:1889-97.

151 Lobo DV, Chu P, Grekin RC et al. Nonmelanoma skin cancers and infection with the human immunodeficiency virus. Arch Dermatol 1992; 128:623-7.

152 Steigleder GK. [Metastasizing basalioma in AIDS]. Z Hautkr 1987; 62:661 (German).

153 Sitz KV, Keppen M, Johnson DF. Metastatic basal cell carcinoma in acquired immunodeficiency syndrome-related complex. Jama $1987 ; 257: 340-3$.

154 Benacerraf B. Role of MHC gene products in immune regulation. Science 1981; 212:1229-38.

155 Dausset J, Colombani J, Hors J. Major histocompatibility complex and cancer, with special reference to human familiar tumors (Hodgkin's disease and other malignancies). Cancer Surv 1982; 1:119-47.

156 Ruiter DJ, Bergman W, Welvaart K et al. Immunohistochemical analysis of malignant melanomas and nevocellular nevi with monoclonal antibodies to distinct monomorphic determinants of HLA-antigens. Cancer Res 1984; 44:3930-4.

157 Myskowsky PL, Safai B, Good RA. Decreased lymphocyte blastogenic response in patients with multiple basal cell carcinomas. J Am Acad Dermatol 1981; 4:711-4.

158 Cabrera T, Garrido V, Concha A et al. HLA molecules in basal cell carcinoma of the skin. Immunobiol 1992; 185:440-52.

159 Garcia-Plata D, Mozos E, Sierra MA et al. HLA expression in basal cell carcinomas. Inv Met 1991; 11:166-73. 
160 Bouwes Bavinck JN, Bastiaens MT, Marugg ME et al. Further evidence for an association of HLA-DR7 with basal cell carcinoma on the tropical island of Saba. Arch Dermatol 2000; 136:1019-22.

161 Rompel R, Petres J, Kaupert K et al. HLA phenotype and multiple basal cell carcinomas. Dermatology 1994; 189:222-4.

162 Rompel R, Petres J, Kaupert K et al. Human leukocyte antigens and multiple basal cell carinomas. Rec Res Canc Res 1995; 139:297302.

163 Czarnecki D, Lewis A, Nicholson I et al. HLA-DR1 is not a sign of poor prognosis for the development of multiple basal cell carcinomas. J Am Acad Dermatol 1992; 26:717-9.

164 Bavinck JN, Kootte AMM, Van der Woude FJ et al. HLA-A11-associated resistance to skin cancer in renal transplant recipients. $\mathrm{N}$ Engl J Med 1990; 323:1350.

165 Bouwes Bavinck JN, Claas FHJ, Hardie DR et al. Relation between HLA antigens and skin cancer in renal transplant recipients in Queensland. Australia J Invest Dermatol 1997; 108:708-11.

166 Galloway DA, McDougall JK. Human papillomaviruses and carcinomas. Adv Virus Res 1989; 37:125-71.

167 Shamanin V, Zur Hausen H, Lavergne D et al. Human papillomavirus infections in nonmelanoma skin cancers from renal transplant recipients and nonimmunosuppressed patients. J Natl Cancer Inst 1996; 88:802-11.

168 Zackheim HS. Origin of the human basal cell epithelioma. J Invest Dermatol 1963; 40:283-97.

169 Krueger K, Blume-Peytavi U, Orfanos CE. Basal cell carcinoma possibly originates from the outer root sheath and/or the bulge region of the vellus hair follicle. Arch Dermatol Res 1999; 291:2539.

170 Lacour JP. Carcinogens of basal cell carcinomas. genetics and molecular mechanisms. Br J Dermatol 2002; 146:17-9.

171 Owens DM, Watt FM. Contribution of stem cells and differentiated cells to epidermal tumours. Nat Rev Cancer 2003; 3:444-51.

172 Potten CS, Morris RJ. Epithelial stem cells in vivo. J Cell Sci Suppl $1988 ; 10: 45-62$.

173 Reya T, Morrison SJ, Clarke MF et al. Stem cells, cancer, and cancer stem cells. Nature 2001; 414:105-11.

174 Miller SJ, Sun TT, Lavker RM. Hair follicles, stem cells and skin cancer. J Invest Dermatol 1993; 100:288S-94S.

175 Brash DE, Rudolph JA, Simon JA et al. A role for sunlight in skin cancer: UV-induced p53 mutations in squamous cell carcinoma. Proc Natl Acad Sci USA 1991; 88:10124-8.

176 Taylor G, Lehrer MS, Jensen PJ et al. Involvement of follicular stem cells in forming not only the follicle but also the epidermis. Cell 2000; 102:451-61.

177 Cotsarelis G, Sun TT, Lavker RM. Label-retaining cells reside in the bulge of the pilosebaceous unit: implications for follicular stem cells, hair cycle and skin carcinogenesis. Cell 1990; 61:1329-37.

178 Alonso L, Fuchs E. Stem cells of the skin epithelium. Proc Natl Acad Sci USA 2003; 100 (Suppl. 1): 11830-5.

179 Tumbar T, Guasch G, Greco V et al. Defining the epithelial stem cell niche in skin. Science 2004; 303:359-63.

180 Zackheim HS. Comparative cutaneous carcinogenesis in the rat. Differential response to the application of anthracene, methylcholanthrene and dimethylbenzanthracene. Oncology 1964; $17: 236$.

181 Kore-eda S, Horiguchi Y, Ueda M et al. Basal cell carcinoma cells resemble follicular matrix cells rather than follicular bulge cells: immunohistochemical and ultrastructural comparative studies. Am J Dermatopathol 1998; 20:362-9.

182 Walsh N, Ackerman AB. Infundibulocystic basal cell carcinoma: a newly described variant. Modern Pathol 1990; 3:599-608.
183 Asada M, Schaart F-M, De Almeida HL et al. Solid basal cell epithelioma (BCE) possibly originates from the outer root sheath of the hair follicle. Acta Derm Venereol (Stockh) 1993; 73:286-92.

184 Gho CG, Braun JE, Tilli CM et al. Human follicular stem cells: their presence in plucked hair and follicular cell culture. Br J Dermatol 2004; 150:860-8.

185 Miller SJ, Wei ZG, Wilson C et al. Mouse skin is particularly susceptible to tumor initiation during early anagen of the hair cycle: possible involvement of hair follicle stem cells. J Invest Dermatol 1993; 101:591-4.

186 Bernemann T-M, Podda M, Wolter $\mathrm{M}$ et al. Expression of the basal cell adhesion molecule (B-CAM) in normal and diseased human skin. J Cutan Pathol 2000; 27:108-11.

187 Kanitakis J, Bourchany D, Faure M et al. Expression of the hair stem cell-specific keratin 15 in pilar tumors of the skin. Eur J Dermatol 1999; 9:363-5.

188 Howell JB, Mehregan AH. Pursuit of the pits in the nevoid basal cell carcinoma syndrome. Arch Dermatol 1970; 102:586-97.

189 Baserga R. The biology of cell reproduction. Cambridge, MA: Harvard University Press, 1985.

190 Tsao H. Genetics of nonmelanoma skin cancer. Arch Dermatol 2001; 137:1486-92.

191 Hockenbery D, Nunez G, Milliman C et al. Bcl-2 is an inner mitochondrial membrane protein that blocks programmed cell death. Nature 1990; 348:334-6.

192 Hunter T. Cooperation between oncogenes. Cell 1991; 64:24970.

193 Anderson E, Howell T. Breast cancer: oncogenes and suppressor genes. Ann Oncol 1990; 1:242-3.

194 Varmus HE. The molecular genetics of cellular oncogenes. Annu Rev Genet 1984; 18:553-612.

195 Suarez HG. Activated oncogenes in human tumors. Anticancer Res 1989; 9:1331-43.

196 Chen YC, Chen PJ, Yeh SH et al. Deletion of the human retinoblastoma gene in primary leukemias. Blood 1990; 76:2060-4.

197 Klein G. Genes that can antagonize tumor development. Faseb J 1993; 7:821-5.

198 Marshall CJ. Tumor suppressor genes. Cell 1991; 64:313-26.

199 Vogelstein B, Kinzler KW. The multistep nature of cancer. Trends Genet 1993; 9:138-41.

200 Rees JL, Healy E. Molecular genetic approaches to non-melanoma and melanoma skin cancer. Clin Exp Dermatol 1996; 21:253-62.

201 Abdelsayed RA, Guijarro-Rojas M, Ibrahim NA et al. Immunohistochemical evaluation of basal cell carcinoma and trichepithelioma using Bcl-2, Ki67, PCNA and p53. J Cutan Pathol 2000; 27:169-75.

202 Baum H-P, Meurer I, Unteregger G. Ki-67 antigen expression and growth pattern of basal cell carcinomas. Arch Dermatol Res 1993; 285:291-5.

203 Horlock NM, Wilson GD, Daley FM et al. Cellular proliferation characteristics of basal cell carcinoma: relationship to clinical subtype and histopathology. Eur J Surg Oncol 1997; 23:247-52.

204 Naeyaert JM, Pauwels C, Geerts ML et al. CD-34 and Ki-67 staining patterns of basaloid follicular hamartoma are different from those in fibroepithelioma of Pinkus and other variants of basal cell carcinoma. J Cutan Pathol 2001; 28:538-41.

205 Chang CH, Tsai RK, Chen GS et al. Expression of bcl-2, p53 and Ki-67 in arsenical skin cancers. J Cutan Pathol 1998; 25:457-62.

206 Tilli CMLJ, Stavast-Kooy AJW, Ramaekers FCS et al. Bax expression and growth behavior of basal cell carcinomas. J Cutan Pathol 2002; 29:79-87.

207 Kazantseva IA, Khlebnikova AN, Babaev VR. Immunohistochemical study of primary and recurrent basal cell and metatypical carcinomas of the skin. Am J Dermatopathol 1996; 18:35-42. 
208 Toth DP, Guenther LC, Shum DT. Proliferating cell nuclear antigen (PCNA); prognostic value in the clinical recurrence of primary basal cell carcinoma. J Dermatol Sci 1996; 11:36-40.

209 Grimwood RE, Ferris CF, Mercill DB et al. Proliferating cells of human basal cell carcinoma are located on the periphery of tumor nodules. J Invest Dermatol 1986; 86:191-4.

210 Coates PJ, Hobbs RC, Crocker J et al. Identification of the antigen recognized by the monoclonal antibody BU31 as lamins A and C. J Pathol 1996; 178:21-9.

211 Lin F, Worman HJ. Structural organization of the human gene encoding nuclear lamin A and nuclear lamin C. J Biol Chem 1993; 268:16321-6.

212 Machiels BM, Zorenc AHG, Endert JM et al. An alternative splicing product of the lamin A/C gene lacks exon 10. J Biol Chem 1996; 271:9249-53.

213 Replogle-Schwab R, Pienta KJ, Getzenberg RH. The utilization of nuclear matrix proteins for cancer diagnosis. Crit Rev Eukaryot Gene Expr 1996; 6:103-13.

214 Roeber RA, Weber K, Osborn M. Differential timing of nuclear lamin $\mathrm{A} / \mathrm{C}$ expression in the various organs of the mouse embryo and the young animal: a developmental study. Development 1989; 105:365-78.

215 Venables RS, McLean S, Luny D et al. Expression of individual lamins in basal cell carcinomas of the skin. Br J Cancer 2001; 84:512-9.

216 Broers JLV, Machiels BM, Kuijpers HJH et al. A- and B-type lamins are differentially expressed in normal human tissues. Histochem Cell Biol 1997; 107:505-17.

217 Oguchi M, Sagara J, Matsumoto K et al. Expression of lamins depends on epidermal differentiation and transformation. Br J Dermatol 2002; 147:853-8.

218 Tilli CM, Ramaekers FC, Broers JL et al. Lamin expression in normal human skin, actinic keratosis, squamous cell carcinoma and basal cell carcinoma. Br J Dermatol 2003; 148:102-9.

219 Heenen M, Achten G, Galand P. Autoradiographic analysis of cell kinetics in human normal epidermis and basal cell carcinoma. Cancer Res 1973; 33:123-7.

220 Kerr JF, Wyllie AH, Currie AR. Apoptosis a basic biological phenomenon with wide-ranging implications in tissue kinetics. Br J Cancer 1972; 26:239-57.

221 Mooney EE, Ruis Peris JM, O’Neill A, Sweeney EC. Apoptotic and mitotic indices in malignant melanoma and basal cell carcinoma. J Clin Pathol 1995; 48:242-4.

222 Wyllie AH, Kerr JFR, Currie AR. Cell death: the significance of apoptosis. Int Rev Cytol 1980; 68:251-306.

223 Raff MC, Durand B, Gao FB. Cell number control and timing in animal development: the oligodendrocyte cell lineage. Int J Dev Biol 1998; 42:263-7.

224 McDonnell TJ, Marin MC, Hsu B et al. The bcl-2 oncogene: apoptosis and neoplasia. Radiat Res 1993; 136:307-12.

225 Majno G, Joris I. Apoptosis oncosis and necrosis. An overview of cell death. Am J Pathol 1995; 146:3-15.

226 Zimmermann KC, Bonzon C, Green DR. The machinery of programmed cell death. Pharmacol Ther 2001; 92:57-70.

227 Peter ME, Krammer PH. Mechanism of CD95 (APO-1/Fas) mediated apoptosis. Curr Opin Immunol 1998; 10:545-51.

228 Suda T, Takahashi T, Golstein P et al. Molecular cloning and expression of the Fas ligand, a novel member of the tumor necrosis factor family. Cell 1993; 75:1169-78.

229 Nagata S, Golstein P. The Fas death factor. Science 1995; 267:1449-56.

230 Cory S. Regulation of lymphocyte survival by the bcl-2 gene family. Annu Rev Immunol 1995; 13:513-43.
231 Gross A, McDonnell TJ, Korsmeyer SJ. Bcl-2 family members and the mitochondria in apoptosis. Genes Dev 1999; 13:1899-911.

232 Tsujimoto Y, Finger LR, Yunis J et al. Cloning of the chromosome breakpoint of neoplastic B cells with the t (14:18) chromosome translocation. Science 1984 226:1097-9.

233 Cleary ML, Smith SD, Sklar J. Cloning and structural analysis of cDNAs for Bcl-2 and a hybrid bcl-2/immunoglobulin transcript resulting from the $\mathrm{t}(14: 18)$ translocation. Cell 1986 47:19-28.

234 Boise LH, Gonzalez-Garcia M, Postema CE et al. Bcl-x, a bcl2-related gene that functions as a dominant regulator of apoptotic cell death. Cell 1993; 74:597-608.

235 Korsmeyer SJ. Bcl-2 initiates a new category of oncogenes: regulators of cell death. Blood 1992; 80:879-86.

236 Chiou SK, Rao L, White E. Bcl-2 blocks p53-dependent apoptosis. Mol Cell Biol 1994; 14:2556-63.

237 Alnemri ES, Fernandes TF, Haldar S et al. Involvement of BCL-2 in glucocorticoid-induced apoptosis of human pre-B-leukemias. Cancer Res 1992; 52:491-5.

238 Bissonnette RP, Echeverri F, Mahboubi A et al. Apoptotic cell death induced by c-myc is inhibited by bcl-2. Nature 1992; 359:552-4.

239 Krajewski S, Tanaka S, Takayama S et al. Investigation of the subcellular distribution of the bcl-2 oncoprotein: residence in the nuclear envelope, endoplasmic reticulum, and outer mitochondrial membranes. Cancer Res 1993; 53:4701-14.

240 Ito T, Deng X, Carr B. Bcl-2 phosphorylation required for antiapoptosis function. J Biol Chem 1997; 272:11671-3.

241 Adams JA, Cory S. The Bcl-2 protein family: arbiters of cell survival. Science 1998; 281:1322-5.

242 Reed JC, Zha H, Aime-Sempe C et al. Structure-function analysis of Bcl-2 family proteins. Regulators of programmed cell death. Adv Exp Med Biol 1996; 406:99-112.

243 Sato T, Hanada M, Bodrug S et al. Interactions among members of the Bcl-2 protein family analyzed with a yeast two-hybrid system. Proc Natl Acad Sci USA 1994; 91:9238-42.

244 Oltvai ZN, Milliman CL, Korsmeyer SJ. Bcl-2 heterodimerizes in vivo with a conserved homolog, Bax, that accelerates programmed cell death. Cell 1993; 74:609-19.

245 Alnemri ES, Livingston DJ, Nicholson DW et al. Human ICE/CED3 protease nomenclature. Cell 1996; 87:171.

246 Nicholson DW, Thornberry NA. Caspases killer proteases. Trends Biochem Sci 1997; 22:299-306.

247 Van de Craen M, Van Loo G, Pype S et al. Identification of a new caspase homologue: caspase-14. Cell Death Differ 1998; 5:838-46.

248 Stennicke HR, Salvesen GS. Properties of the caspases. Biochim Biophys Acta 1998; 1387:17-31.

249 Enari M, Sakahira H, Yokomaya $\mathrm{H}$ et al. A caspase-activated DNAse that degrades DNA during apoptosis, and its inhibitor CAD. Nature 1998; 391:43-50.

250 Liu X, Zou H, Slaughter C et al. DFF, a heterodimeric protein that functions downstream of caspase-3 to trigger DNA fragmentation during apoptosis. Cell 1997; 89:175-84.

251 Takahashi A, Alnemri ES, Lazebnik YA et al. Cleavage of lamin A by Mch2alpha but not CPP32: multiple interleukin 1beta-converting enzyme-related proteases with distinct substrate recognition properties are active in apoptosis. Proc Natl Acad Sci USA 1996; 93:8395-400.

252 Orth $\mathrm{K}$, Chinnaiyan AM, Garg M et al. The CED-3/ICE-like protease Mch2 is activated during apoptosis and and cleaves the death substrate lamin A. J Biol Chem 1996; 271:16443-6.

$253 \mathrm{Ku}$ NO, Omary MB. Effect of mutation and phosphorylation of type I keratins on their caspase-mediated degradation. J Biol Chem 2001; 276:26792-8. 
254 Martin SJ, Finucane DM, Amarante-Mendes GP et al. Phosphatidylserine externalization during CD-95-induced apoptosis of cells and cytoplasts requires ICE/CED-3 protease activity. J Biol Chem 1996; 271:28753-6.

255 Casiano CA, Martin SJ, Green DR, Tan EM. Selective cleavage of nuclear autoantigens during CD95 (Fas/APO-1)-mediated T cell apoptosis. J Exp Med 1996; 184:765-70.

256 Deveraux QL, Takahashi R, Salvesen GS et al. X-linked IAP is a direct inhibitor of cell-death proteases. Nature 1997; 388:300-4.

257 Roy N, Deveraux QL, Takahashi R et al. The c-IAP-1 and c-IAP-2 proteins are direct inhibitors of specific caspases. EMBO J 1997; 16:6914-25.

258 Polakowska RR, Piacentini M, Bartlett R et al. Apoptosis in human skin development: morphogenesis, periderm, and stem cells. Dev Dyn 1994; 199:176-88.

259 Weil M, Raff MC, Braga VM. Caspase activation in the terminal differentiation of human epidermal keratinocytes. Curr Biol 1999; 9:361-4.

260 Tyrrell RMUV activation of mammalian stress proteins. EXS 1996; 77:255-71.

261 Wikonkal NM, Berg RJW, van Haselen CW et al. Bcl-2 versus p53 protein expression and apoptotic rate in human nonmelanoma skin cancers. Arch Dermatol 1997; 133:599-602.

262 Bolshakov S, Walker CM, Strom SS et al. p53 mutations in human aggressive and nonaggressive basal and squamous cell carcinomas. Clin Cancer Res 2003; 9:228-34.

263 Staibano S, Lo Muzio L, Pannone G et al. Interaction between bcl2 and P53 in neoplastic progression of basal cell carcinoma of the head and neck. Anticancer Res 2001; 21:3757-64.

264 Delehedde M, Cho SH, Sarkiss M et al. Altered expression of bcl-2 family member proteins in nonmelanoma skin cancer. Cancer 1999; 85:1514-22.

265 Cerroni L, Kerl H. Aberrant bcl-2 protein expression provides a possible mechanism of neoplastic cell growth in cutaneous basal cell carcinoma. J Cutan Pathol 1994; 21:398-403.

266 Verhaegh MEJM, Sanders CJG, Arends JW et al. Expression of the apoptosis-suppressing protein bcl-2 in non-melanoma skin cancer. Br J Dermatol 1995; 132:740-4.

267 Rodriguez-Villanueva J, Colome MI, Brisbay S et al. The expression and localization of bcl-2 protein in normal skin and in nonmelanoma skin cancers. Path Res Pract 1995; 191:391-8.

268 Morales-Ducret JCR, Van de Rijn M, LeBrun DP et al. Bcl-2 expression in primary malignancies of the skin. Arch Dermatol 1995; 131:909-12.

269 Grossman D, McNiff JM, Li F et al. Expression of the apoptosis inhibitor, survivin, in nonmelanoma skin cancer and gene targeting in a keratinocyte cell line. Lab Invest 1999; 79:1121-6.

270 Hill LL, Ouhtit A, Loughlin SM et al. Fas ligand: a sensor for DNA damage critical in skin cancer etiology. Science 1999; 285:898-900.

271 Filipowicz E, Adegboyega P, Sanchez RL et al. Expression of CD95 (fas) in sun-exposed human skin and cutaneous carcinomas. Cancer 2002; 94:814-9.

272 Gutierrez-Steil C, Wrone-Smith T, Sun X et al. Sunlight-induced basal cell carcinoma tumor cells and ultraviolet-B-irradiated psoriatic plaques express Fas ligand (CD95L). J Clin Invest 1998; 101:33-9.

273 Albright SD 3rd. Treatment of skin cancer using multiple modalities. J Am Acad Dermatol 1982; 7:143-71.

274 Telfer NR, Colver GB, Bowers PW, Guidelines for the management of basal cell carcinomas. British Association of Dermatologists. Br J Dermatol 1999; 141:415-23.

275 Thissen MRTM, Schroeter CA, Neumann HAM. Effective photodynamic therapy with 5-aminolevulinic acid for nodular basal cell carcinomas using a preceding debulking technique. Br J Dermatol 2000; 142:338-9.

276 Miller BH, Shavin JS, Cognetta A et al. Nonsurgical treatment of basal cell carcinomas with intralesional 5-fluorouracil/epinephrine injectable gel. J Am Acad Dermatol 1997; 36:72-7.

277 Park AJ, Strick M, Watson JD. Basal cell carcinomas: do they need to be followed up? J R Coll Surg Edinb 1994; 39:109-11.

278 van der Meer GT, Willemse F, Marck KW. [Low 5-year recurrence rate after surgical excision of 126 basal cell carcinomas with frozen section analysis upon indication]. Ned Tijdschr Geneeskd 2001; 145:1409-13. (Dutch).

279 Fisher DE. Apoptosis in cancer therapy: crossing the threshold. Cell 1994; 78:539-42.

280 Jee SH, Shen SC, Chiu HC et al. Overexpression of interleukin-6 in human basal cell carcinoma cell lines increases anti-apoptoticactivity and tumorigenic potency. Oncogene 2001; 20:198-208.

281 Jee SH, Shen SC, Tseng CR et al. Curcumin induces a p53-independent apoptosis in human basal cell carcinoma cells. J Invest Dermatol 1998; 111:656-61.

282 Huang Z. Bcl-2 family proteins as targets for anticancer drug design. Oncogene 2000; 19:6627-31.

283 Rodriguez-Villanueva J, McDonnell TJ, Induction of apoptotic cell death in non-melanoma skin cancer by interferon-alpha. Int J Cancer 1995; 61:110-4.

284 Buechner SA, Wernli M, Harr T et al. Regression of basal cell carcinoma by intralesional interferon-alpha treatment is mediated by CD95 (APO-1/FAS)-CD95 ligand-induced suicide. J Clin Invest 1997; 100:2691-6.

285 Romagosa R, Saap L, Givens M et al. A pilot study to evaluate the treatment of basal cell carcinoma with 5 -fluorouracil using phosphatidyl choline as a transepidermal carrier. Dermatol Surg 2000; 26:338-40.

286 Brash DE, Ponten J. Skin precancer. Cancer Surveys 1998; 32:69113.

287 Nakaseko H, Kobayashi M, Akita Y et al. Histological changes and involvement of apoptosis after photodynamic therapy for actinic keratoses. Br J Dermatol 2003; 148:122-7.

288 Kalka K, Merk H, Mukhtar H. Photodynamic therapy in dermatology. J Am Acad Dermatol 2000; 42:389-413.

289 Hoffman EJ. Cancer and the Search for Selective Biochemical Inhibitors. Boca Raton, FL. CRC Press. 1999.

290 Levin C, Maibach H. Exploration of 'alternative' and 'natural' drugs in dermatology. Arch Dermatol 2002; 138:207-11.

291 Elmets CA, Singh D, Tubesing K et al. Cutaneous photoprotection from ultraviolet injury by green tea polyphenols. J Am Acad Dermatol 2001; 44:425-32.

292 Zhao J, Jin X, Yaping E et al. Photoprotective effects of black tea extracts against UVB-induced phototoxicity in skin. Photochem Photobiol 1999; 70:637-44.

293 Lu YP, Lou YR, Xie JG et al. Inhibitory effect of black tea on the growth of established skin tumors in mice: effects on tumor size, apoptosis, mitosis and bromodeoxyuridine incorporation into DNA. Carcinogenesis 1997; 18:2163-9.

294 Apitz-Castro R, Ledezma E, Escalante J et al. Reversible prevention of platelet activation by (E,Z)-4,5,9-trithiadodeca-1,6,11-triene 9-oxide (ajoene) in dogs under extracorporeal circulation. Arzneimittelforschung 1988; 38:901-4.

295 Dirsch VM, Gerbes AL, Vollmar AM. Ajoene a compound of garlic, induces apoptosis in human promyeloleukemic cells, accompanied by generation of reactive oxygen species and activation of nuclear factor kappaB. Mol Pharmacol 1998; 53:402-7.

296 Tilli CM, Stavast-Kooy AJ, Vuerstaek JD et al. The garlic-derived organosulfur component ajoene decreases basal cell carcinoma 
1124 Molecular aetiology and pathogenesis of BCC, C.M.L.J. Tilli et al.

tumor size by inducing apoptosis. Arch Dermatol Res 2003; 295:117-23.

297 Taipale J, Chen JK, Cooper MK et al. Effects of oncogenic mutations in Smoothened and Patched can be reversed by cyclopamine. Nature 2000; 406:1005-9.

298 Chen JK, Taipale J, Young KE et al. Small molecule modulation of Smoothened activity. Proc Natl Acad Sci USA 2002; 99:14071-6.

299 Tas S, Avci O. Induction of the differentiation and apoptosis of tumor cells in vivo with efficiency and selectivity. Eur J Dermatol 2004; 14:96-102.

300 Lotan R. Retinoids in cancer prevention. Faseb J 1996; 10:10319.

301 Van Heusden J, Van Ginckel R, Bruwiere H et al. Inhibition of all-TRANS-retinoic acid metabolism by R1 16010 induces antitumour activity. Br J Cancer 2002; 86:605-11.

302 Goss PE, Strasser K, Marques R et al. Liarozole fumarate (R85246): in the treatment of ER negative, tamoxifen refractory or chemotherapy resistant postmenopausal metastatic breast cancer. Breast Cancer Res Treat 2000; 64:177-88.

303 Cowen E, Mercurio MG, Gaspari AA. An open case series of patients with basal cell carcinoma treated with topical 5\% imiquimod cream. J Am Acad Dermatol 2002; 47:S240-8.
304 Chen TM, Rosen T, Orengo I. Treatment of large superficial basal cell carcinoma with 5\% imiquimod: a case report and review of the literature. Dermatol Surg 2002; 28:344-6.

305 Drehs MM, Cook-Bolden F, Tanzi EL et al. Successful treatment of multiple superficial basal cell carcinomas with topical imiquimod: case report and review of the literature. Dermatol Surg 2002; 28:427-9.

306 Geisse JK, Rich P, Pandya A et al. Imiquimod 5\% cream for the treatment of superficial basal cell carcinoma: a double-blind, randomized, vehicle-controlled study. J Am Acad Dermatol 2002; 47:390-8.

307 Callahan CA, Oro AE. Monstrous attempts at adnexogenesis: regulating hair follicle progenitors through Sonic hedgehog signaling. Curr Opin Genet Dev 2001; 11:541-6.

308 Saldanha G, Fletcher A, Slater DN. Basal cell carcinoma: a dermatopathological and molecular biological update. $\mathrm{Br} \mathrm{J}$ Dermatol 2003; 148:195-202. 